\title{
The Trajectory of Two Decades of Global Journal of Flexible Systems Management and Flexibility Research: A Bibliometric Analysis
}

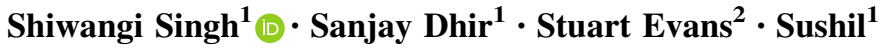

Received: 14 July 2021/Accepted: 12 August 2021/Published online: 5 September 2021

(C) Global Institute of Flexible Systems Management 2021

\begin{abstract}
In the year 2020, the Global Journal of Flexible Systems Management (GJFSM) has celebrated its two decades of publication. This study is an attempt to commemorate the two decades of publication by presenting the overview of the GJFSM along with the trajectory of flexibility research in various journals. By using multiple bibliometric tools and indicators, the study finds that the GJFSM has grown over the years in terms of total publications and citations. The contributors are from across the globe, i.e., South America, North America, Asia, Europe, Africa, and the Pacific. The Journal publishes several flexibility areas, including information systems flexibility, financial flexibility, supply chain flexibility, technology management flexibility, marketing flexibility, organizational flexibility, strategic flexibility, and manufacturing flexibility. The GJFSM is cited by authors from various countries across the globe. It has been cited across different Scopus categorizations, including "Strategy and Management," "Business and International Management," "General Business, Management and Accounting,"
\end{abstract}

Shiwangi Singh

shiwangi.iitd@gmail.com

Sanjay Dhir

sanjaydhir@dms.iitd.ac.in; sanjaydhir.iitd@gmail.com

Stuart Evans

stuart.evans@sv.cmu.edu

Sushil

sushil@dms.iitd.ac.in; profsushil@gmail.com

1 Department of Management Studies, Indian Institute of Technology Delhi, New Delhi 110016, India

2 Integrated Innovation Institute, Carnegie Mellon University, Silicon Valley Campus, NASA Ames Research Park, Moffett Field, CA 94035-0001, USA
"Industrial and Manufacturing Engineering," and "Management Science and Operations Research." Keyword cooccurrences analysis helps to analyze the various groups of keywords cited together in the GJFSM. Co-citation analysis of references helps to identify crucial clusters of GJFSM, i.e., strategic flexibility, manufacturing flexibility, the conceptual framework of flexibility, supply chain flexibility, modeling flexibility, and application of TISM. Overall, GJFSM has seen an increase in both publications and citations, reflecting its increasing presence among the journals publishing flexibility research. The diversity of flexibility research and its contributions to research underone-roof make this Journal unique. The paper concludes with the gap areas of flexibility research and the way forward.

Keywords Bibliographic coupling.

Bibliometric analysis - Co-citation analysis - Flexibility ·

Global Journal of Flexible Systems Management (GJFSM)

- Keyword co-occurrences

\section{Introduction}

The Global Journal of Flexible Systems Management (GJFSM) is an international peer-reviewed journal founded in 2000. It is published under the auspices of the "Global Institute of Flexible Systems Management" and co-published by Springer since the year 2012. The overall aim of the Journal is to enrich the flexible systems management research base and promote cross-functional flexibility research. The Journal's purpose has been made amply clear in the two editorials (Sushil, 2000, 2012); one highlights its genesis, launch, and innovative features, and the other giving multiple perspectives of flexible systems 
management considered in the Journal. In the area of flexibility, GJFSM is one of the prestigious academic journals (Seebacher \& Winkler, 2013).

Since the inception of the Journal, GJFSM has evolved on various qualitative and quantitative measures. The CiteScore of the Journal has increased from 0.7 in 2011 to 6.8 in 2020. It is registered in Scopus under three categories, i.e., "Business, Management and Accounting (miscellaneous)," "Business and International Management," and "Strategy and Management" and recently it was also included in "Management Information Systems." In 2020, the percentile score of the Journal in "Business, Management and Accounting (miscellaneous)" is 95\%, "Business and International Management" is $90 \%$, "Strategy and Management" is $89 \%$, and "Management Information Systems" is $85 \%$. The SNIP of the Journal has increased from 0.345 in 2011 to 1.472 in 2020 . These metrics show the improvement in the rating and also indicate its reputation in flexibility research.

In 2020, GJFSM celebrated its twentieth anniversary. The study attempts to present an overview of the Journal to commemorate the event. The bibliometric analysis of GJFSM is performed between 2000 and 2020. Extant literature has majorly applied this technique to study the journals (Donthu et al., 2020; Singh et al., 2020a) and topics (Merigó et al., 2019; Rajan et al., 2020; Singh \& Dhir, 2019). For example, Singh et al. (2020a) have studied the "Technological Forecasting and Social Change" journal from 1970 to 2018. Donthu et al. (2020) have studied the "Journal of Business Research" from 1973 to 2017. The inferences from these sources are taken as a basis for this study to conduct an in-depth analysis of its trajectory in terms of publication trend, citation trend, most influential publications, and most prolific countries. This study also provides the bibliographic coupling of countries, geographical classification of countries, special issues overview, and insights into the citing journals and countries for GJFSM. The study also analyzes keyword co-occurrences analysis, the evolution of keywords, and citation analysis. Besides, it helps in the identification of top social science journals in the different areas of flexibility research.

The paper adds to the existing studies in GJFSM and summarizes the research up to the end of 2020. It provides a comprehensive overview of the Journal, including citation structure, publication structure, top publications, and countries. The article enumerates the information on various topics of research in this Journal across different time phases. This will enable the readers to understand the current focus areas of the Journal. This analysis will also help them to have a better idea about the current focus of the Journal and the other journals publishing flexibility research of different types.
In the following sections, the methodology is discussed, results are presented, and the study's conclusions are highlighted.

\section{Methodology}

In the past few years, the number of publications has increased at a rapid pace. The emphasis on different contexts, characteristics, and methods has resulted in a fragmented and voluminous research domain. Therefore, it appears infeasible to analyze such a huge article base and bibliometric information manually. The systematic review of literature helps in analyzing and synthesizing the extant literature. The scholars have identified different quantitative and qualitative methods to review the literature. Among these methods, bibliometric analysis helps in presenting a comprehensive overview of the literature. Bibliometric research analyzes the extensive bibliographic information based on statistical measurements (Broadus, 1987; Diodato, 1994). It provides a transparent, systematic, and reproducible view of the area of study. It helps in performing a structured analysis. It analyzes the bibliographic data to infer the publication and citation trends, themes researched, prominent countries, and presents the comprehensive overview of the domain (Crane, 1972; Pitt et al., 2021).

The bibliometric study data analysis includes descriptive and network analysis (Aria \& Cuccurullo, 2017). The descriptive analysis is based on the total citations, the total publications, and cite ratio. The impact and productivity are measured through the h-index. H-index is equivalent to $\mathrm{n}$ number of published articles having minimum of $\mathrm{n}$ citations each. Along the descriptive analysis, network analysis helps in visualization of the common sources, patterns, and keywords. In this study three major types of network analysis are included, viz. co-occurrences, bibliographic coupling, and co-citation analysis. Bibliographic coupling occurs "when one item of reference is used by two papers" (Kessler, 1963, p. 169). Here, based on common references, the two papers are coupled. Co-citation analysis is referred "as the frequency in which the two documents are cited together" (Small, 1973, p. 265). Keyword co-occurrences depict the knowledge structure of the literature. The study uses VOS viewer software for visualizing the bibliographic network. Further, comparative standing of journals is seen in various flexibility areas by performing the search in Scopus in the "Business, Management, and Accounting" area.

The data were extracted from the Scopus, the most extensive database for peer-reviewed journals in social sciences (Bartol et al., 2014; Dixit et al., 2021; Singh et al., , 2020b, 2021; Srivastava et al., 2020). The key search 
phrase consisted of source "Global Journal of Flexible Systems Management" and filter-type source between 2000 and 2020. The search revealed 463 documents that are used for analysis. In the second part, the key phrases used are flexibility, flexible, and various types of flexibility including manufacturing flexibility, supply chain flexibility, marketing flexibility, financial flexibility, information systems flexibility, organizational flexibility, and strategic flexibility.

\section{Journal Performance and Growth}

The journal performance and growth help to determine the overall growth of the Journal by measuring the impact through various parameters, including Journal CiteScore, percentile score, SNIP (Source Normalized Impact per Paper), SJR (SCImago Journal Rank), quartile scores, citation and publication trend, citation structure, and most cited articles.

\section{Categorization of Published Articles in GJFSM}

The GJFSM aims to enrich the flexible systems management research at a generic level and promotes cross-functional areas of flexibility. The key categories of flexibility research in the GJFSM include "Strategic and Organizational Flexibility," "Manufacturing, Operations and Supply Chain Flexibility," "Information Systems Flexibility," "Financial Flexibility," "Technology and Innovation Management Flexibility," and "Marketing Flexibility." Table 1 highlights that the majority of the articles are published in the area of Strategy and Organization Flexibility $(31.97 \%)$ followed by Manufacturing, Operations and Supply Chain Flexibility (30.02\%) (Table 1; Fig. 1).

Table 1 Categorization of published articles in GJFSM

\begin{tabular}{lc}
\hline Categories & $\begin{array}{l}\text { Percentage } \\
\text { articles } \\
\text { published }(\%)\end{array}$ \\
\hline Strategic and organizational flexibility & 31.97 \\
Manufacturing, operations and supply chain & 30.02 \\
$\quad$ flexibility & 10.37 \\
Information systems flexibility & 5.62 \\
Financial flexibility & 4.54 \\
Technology and innovation management & 3.02 \\
$\quad$ flexibility & 1.94 \\
Marketing flexibility & 12.53 \\
Research tools/methods & 100.00 \\
Others (editorials and short communications) & \\
Total &
\end{tabular}

\section{Key Performance Indicators of GJFSM}

The key performance indicators of the Journal include CiteScore, quartile score, SJR, and SNIP. CiteScore symbolizes the average citations per document received by a journal during a certain time period. It calculates the citations received in 1 year for the documents that are published in the current year and previous three years for a journal. The CiteScore of the Journal has increased from 0.7 in 2011 to 6.8 in 2020 (Fig. 2). The CiteScore percentile shows the relative standing of a journal in various Scopus categories. The Journal is awarded a CiteScore percentile for each category in which the Journal is indexed in. GJFSM is indexed in three categories, i.e., "Business, Management, and Accounting (miscellaneous)," "Business and International Management," and "Strategy and Management," and recently the fourth category is added, i.e., "Management Information Systems." The GJFSM is indexed in "Business, Management, and Accounting (miscellaneous)" since 2019. In 2020, the percentile scores of "Business, Management, and Accounting (miscellaneous)," "Business and International Management," "Strategy and Management," and "Management Information Systems" are 95\%, 90\%, 89\%, and 85\%, respectively (Fig. 3).

SJR indicates "the average number of weighted citations received in a year by the documents published in the Journal in the previous three years" (Janen, 2020, p. 189). SNIP calculates the contextual citation impact. The SJR of the GJFSM has improved from 0.142 in 2007 to 0.819 in 2020, and SNIP has improved from 0.057 in 2003 to 1.472 in 2020 (Fig. 4).

The journals based on the ranking in SJR are divided into four equal quartiles, i.e., Q1, Q2, Q3, and Q4, in various subject categories. The journals in $\mathrm{Q} 1$ are more prestigious and cited often than journals in other quartiles. In 2020, the journal ranked in quartile 1 of "Business, Management and Accounting (miscellaneous)," "Business and International Management," "Strategy and Management," and "Management Information System" (Fig. 5).

\section{Citation and Publication Trend of GJFSM}

GJFSM has published eight articles in the inaugural year and treated it as the incubation year, and thus, the actual two decades are treated as 2001 to 2020 . However, since then the number of publications has grown to 28 articles in 2020 spread across 5 issues, and the average number of articles published in each issue ranges from 5 to 7 . Figure 6 shows the publication trend and citation trend of the GJFSM. Table 19 (in appendix) depicts the publication and citation structure. Overall, from 2000 to 2020, the total 
Fig. 1 Graphical representation of categories of articles published in GJFSM

Fig. 2 CiteScore trajectory of GJFSM (Source: Scopus)
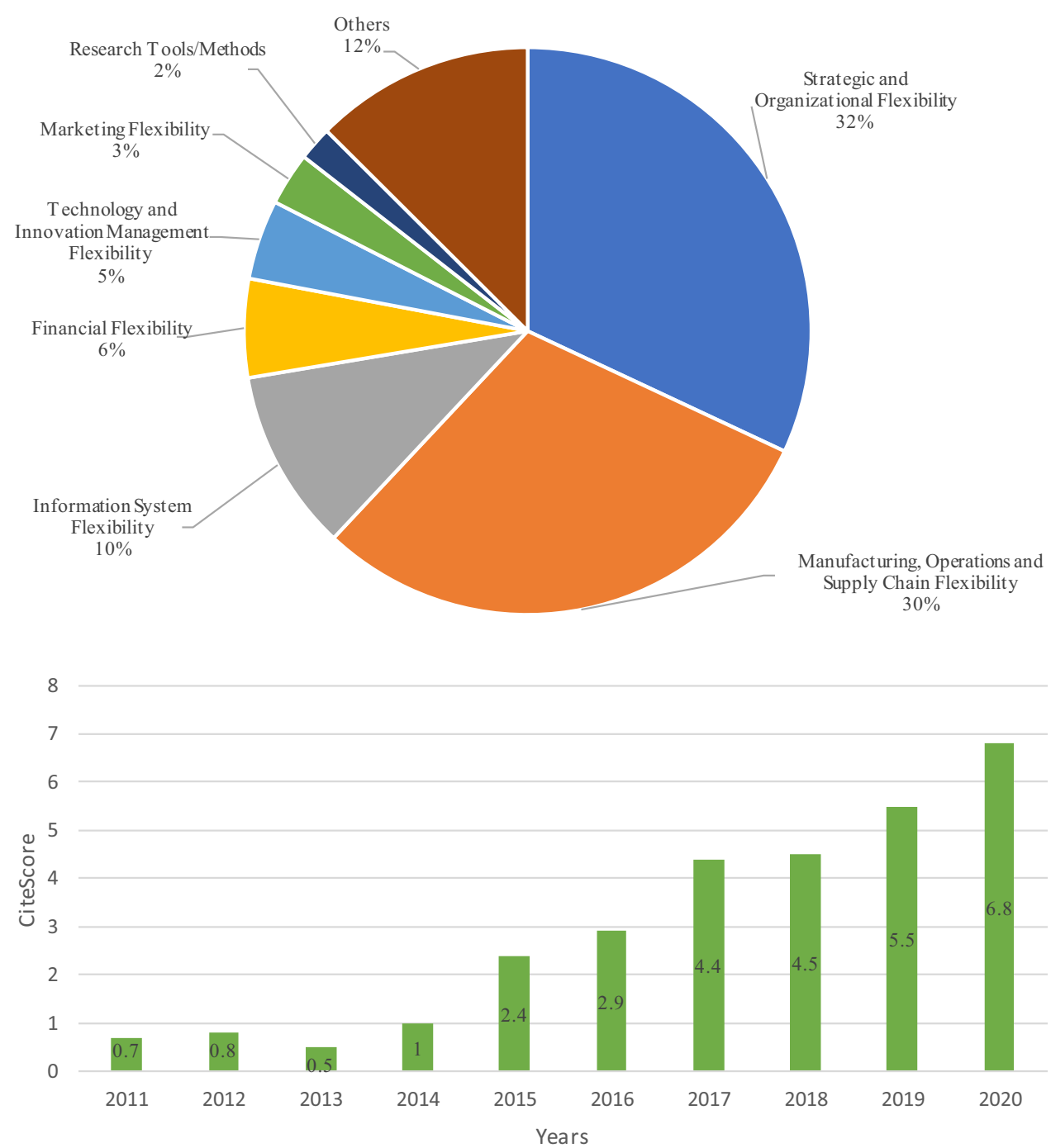

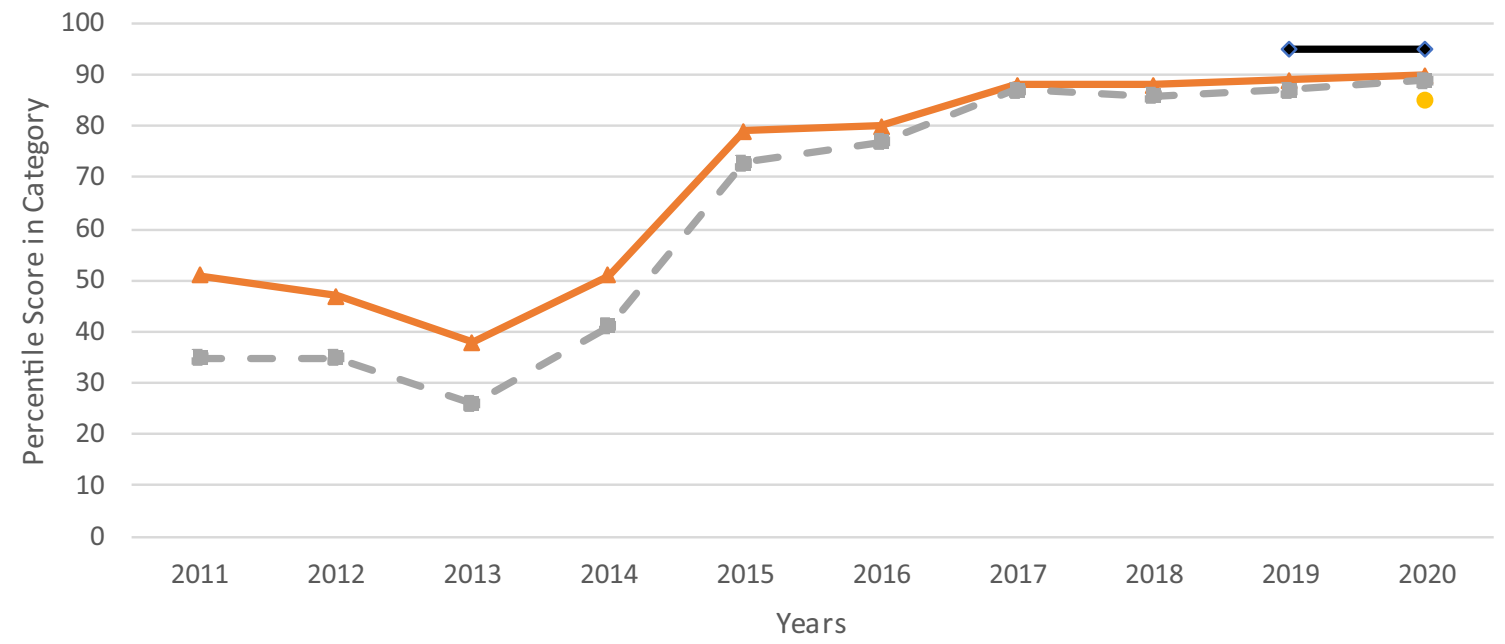

\footnotetext{
$\longrightarrow$ Business, Management, and Accounting $\longrightarrow$ Business and International Management

- Strategy and Management

Management Information Systems
}

Fig. 3 CiteScore percentile score of GJFSM in different categories (Source: Scopus) 


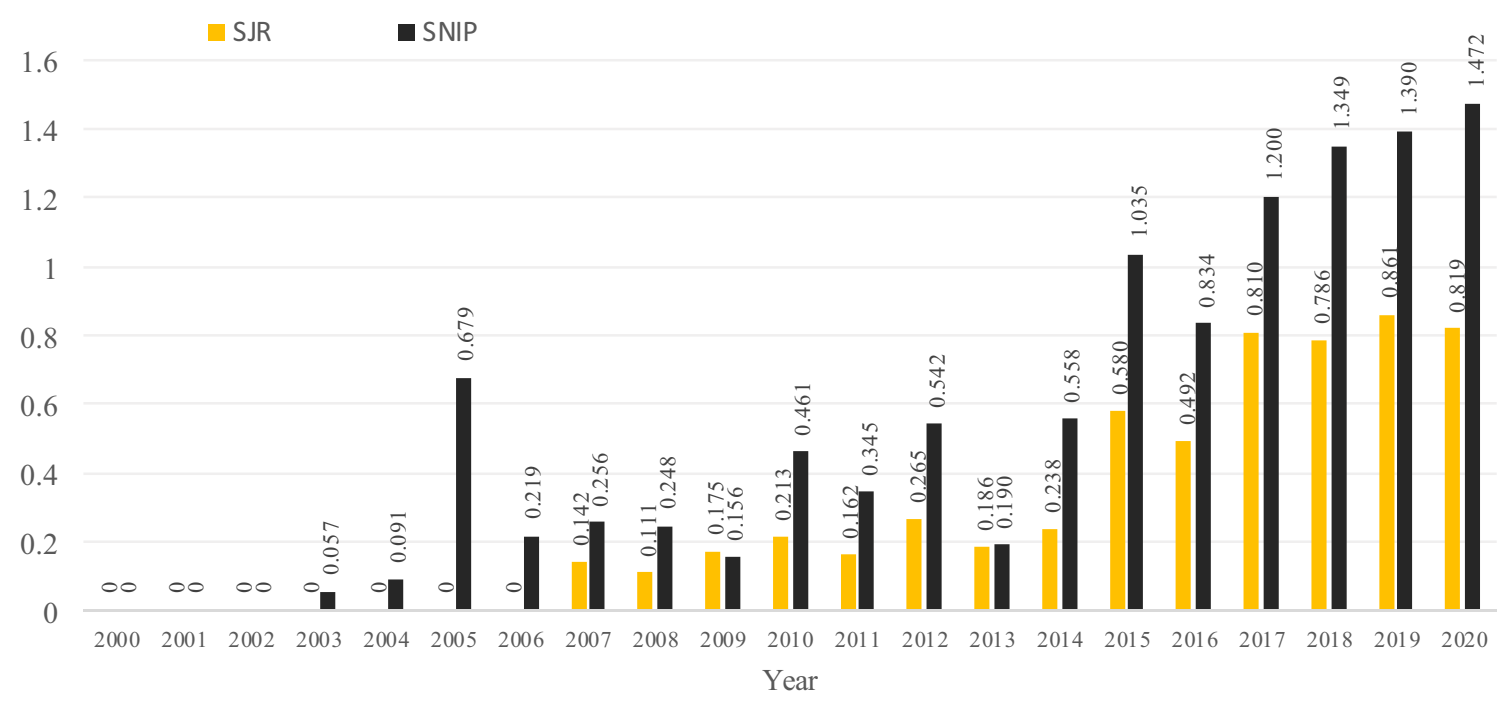

Fig. 4 SJR and SNIP evolution of GJFSM 2000-2020 (Source: Scopus)

\begin{tabular}{|c|c|c|c|c|c|c|c|c|c|c|}
\hline & 2011 & 2012 & 2013 & 2014 & 2015 & 2016 & 2017 & 2018 & 2019 & 2020 \\
\hline $\begin{array}{c}\text { Business and International } \\
\text { Management }\end{array}$ & & & & & & & & & & \\
\hline $\begin{array}{l}\text { Business, Management } \\
\text { and Accounting } \\
\text { (Miscellaneous) }\end{array}$ & & & & & & & & & & \\
\hline Strategy and Management & & & & & & & & & & \\
\hline $\begin{array}{l}\text { Management Information } \\
\text { System }\end{array}$ & & & & & & & & & & \\
\hline $\mathrm{Q} 1$ & & & $\mathrm{Q} 2$ & & & & Q & & & \\
\hline
\end{tabular}

Fig. 5 Quartiles of GJFSM (Source: adapted from SCImago)

number of publications are 463 (all publications) and 393 (excluding editorials and short communications).

The total citations and the total publications are growing. Figure 6 shows that in terms of publications, the year 2014 and 2018 were the most productive years with 31 articles each year, followed by 2016 with 30 articles. Figure 7 shows that the percentage of articles that were published in a year and are not cited. All the articles published in 2015, 2017, and 2018 are cited. Citations indicate the influence of the articles (Tsay, 2009). Therefore, in terms of citations, 2020 was the most productive year, followed by 2019 and 2018. The Journal was indexed in Scopus in the year 2006. Before 2006, the citations per year were less than 30 . After 2006, the Journal has started to receive more citations. Table 19 (in appendix) shows that $13.74 \%$ of articles are cited at least 20 times, $34.86 \%$ of articles are at least cited 10 times, and $90.84 \%$ of articles are at least cited once. The impact of the Journal can be seen through the h-index. The most influential year for impact was 2014, with an h-index of 12; the overall h-index of the Journal is 33. Thus, the publications and citations of GJFSM exhibit a robust and positive growth trajectory.

\section{Most Cited Articles}

As evident across literature that citations reveal the influence of the articles. Table 2 depicts the top 10 most influential publications. The most cited studies are in the area of the interpretive structural model, a research tool (TC: 253) followed by supply chain flexibility (TC: 140), and flexible manufacturing system (TC: 104). Table 2 highlights that the range of publication year is 2003-2017. The $\mathrm{C} / \mathrm{Y}$ ratio is calculated to see the average citations per year. Therefore, it helps to minimize the effect of the year on total citations. The top articles according to cite ratio $(\mathrm{C} /$ $\mathrm{Y})$ are interpretive structural model $(\mathrm{C} / \mathrm{Y}: 31.63)$, Flexible Green Supply Chain Management (C/Y: 18.75), and Big 


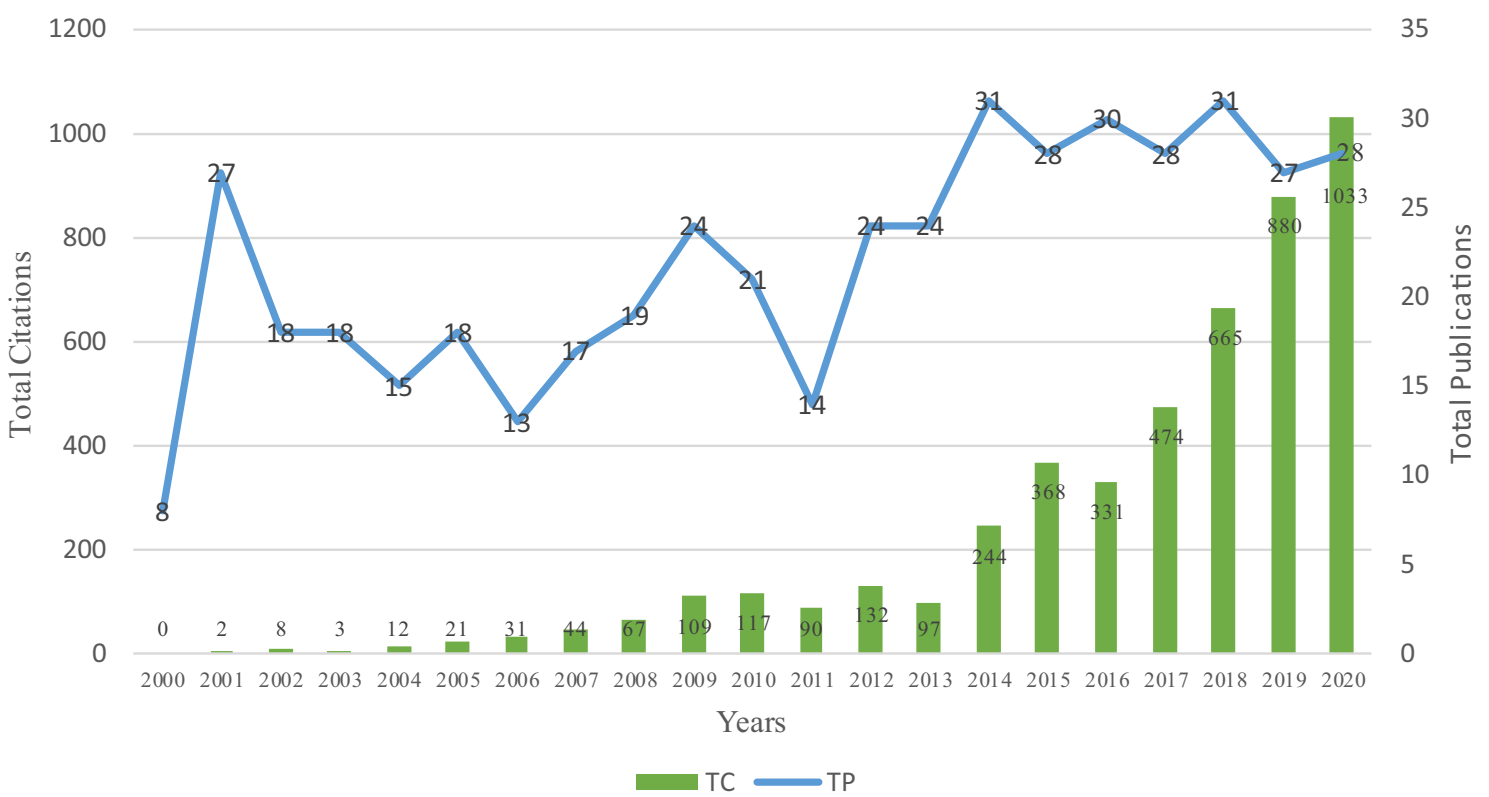

Fig. 6 Annual publication and citation overview of GJFSM (Source: Scopus)

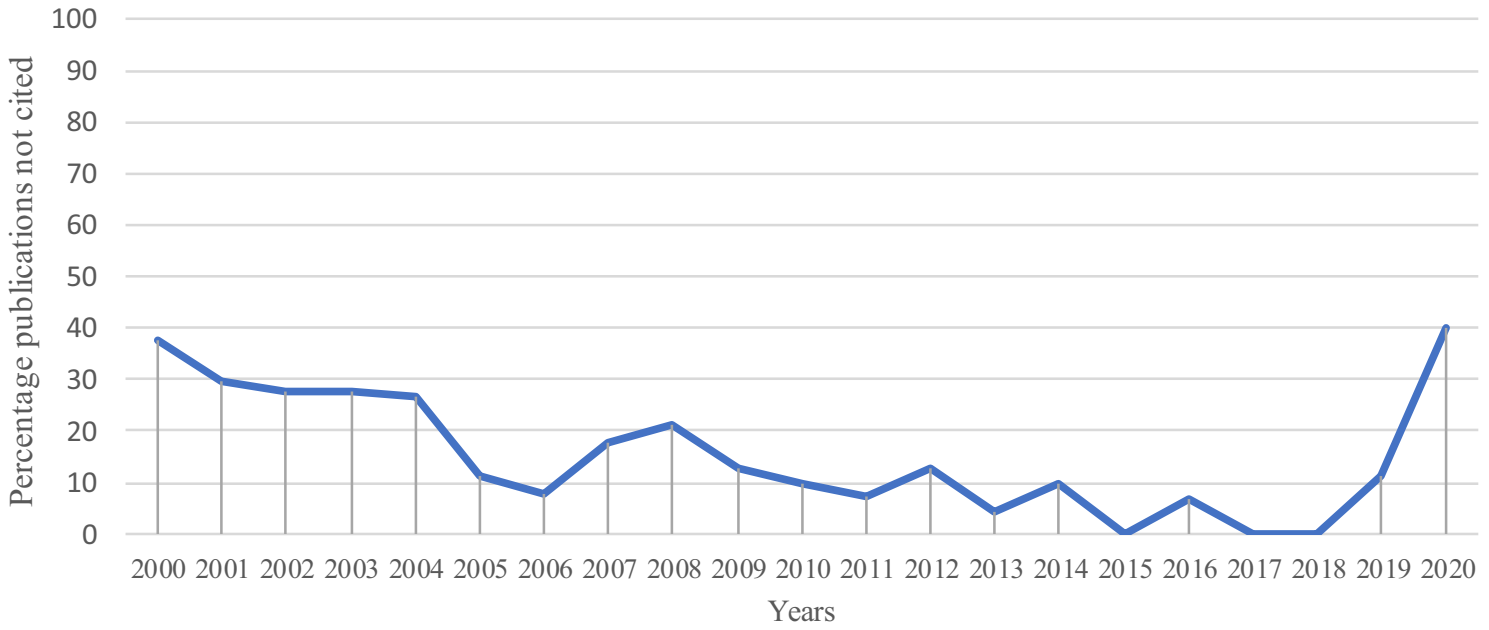

Fig. 7 Percentage publications not cited (Source: Scopus)

Data Analytics (C/Y: 18.33). In the literature (Seebacher and Winkler, 2013) work of Lummus et al. (2003) is considered as one of the most cited paper in the area of supply chain flexibility. More citations were given in the second decade from 2011 to 2020 compared to the first decade up to 2010. Out of the top 10 articles, only three belong to the first decade and the rest seven from the second decade.

\section{Special Issues in GJFSM}

The special issues in GJFSM started in the year 2014. On average, the special issues of the Journal vary from 1 to 2 per year. The number of articles published in these special issues ranges from 5 to 9 . These special issues are published on varied topics, for instance, HR flexibility, supply chain flexibility, organizational flexibility, innovation \& flexibility, and complexity management (Table 3).

\section{Country Analysis}

\section{Most Influential Countries According to Cite Ratio}

Along with the most cited articles, top countries also contribute to the growth of the journals. Table 4 presents the leading countries, their total publications (TP), citations (TC), cite ratio (TC/TP), and their impact measured 
Table 2 Top ten cited articles

\begin{tabular}{|c|c|c|c|c|}
\hline Rank & Title & TC & Year & $\mathrm{C} / \mathrm{Y}$ \\
\hline 1 & Interpreting the interpretive structural model & 253 & 2012 & 31.63 \\
\hline 2 & Supply chain flexibility: building a new model & 140 & 2003 & 8.24 \\
\hline 3 & $\begin{array}{l}\text { Identification of flexible manufacturing system dimensions and their interrelationship using total interpretive structural } \\
\text { modeling and fuzzy MICMAC analysis }\end{array}$ & 104 & 2014 & 17.33 \\
\hline 4 & Flexible decision approach for analyzing performance of sustainable supply chains under risks/uncertainty & 95 & 2014 & 15.83 \\
\hline 5 & Interpretive matrix: a tool to aid interpretation of management and social research & 83 & 2005 & 5.53 \\
\hline 6 & Enablers and barriers of flexible green supply chain management: a total interpretive structural modeling approach & 75 & 2016 & 18.75 \\
\hline 7 & Fuzzy-TISM: a fuzzy extension of TISM for group decision making & 72 & 2015 & 14.40 \\
\hline 8 & $\begin{array}{l}\text { Modeling of continuity and change forces in private higher technical education using total interpretive structural } \\
\text { modeling (TISM) }\end{array}$ & 62 & 2011 & 6.89 \\
\hline 9 & Interpretive ranking process & 58 & 2009 & 5.27 \\
\hline 10 & Big data analytics: a review on theoretical contributions and tools used in literature & 55 & 2017 & 18.33 \\
\hline
\end{tabular}

Table 3 Special issues publication in GJFSM

\begin{tabular}{lll}
\hline Topic & Year & Number of articles published \\
\hline Inter-organizational governance flexibility & $2022^{* *}$ & - \\
Flexibility approaches for addressing sustainable development goals & $2021^{*}$ & - \\
Innovation and flexibility for Covid-19 recovery strategies & 2021 & 5 \\
Enhancing organizational management in Latin America through flexibility: trends and challenges & 2020 & 7 \\
Flexible operations and supply chains & 2019 & 5 \\
The future of manufacturing global value chains, smart specialization and flexibility & 2018 & 6 \\
Models and management of elasticity and openness toward flexible organizations & 2017 & 7 \\
Flexible sustainable supply chain network design & 2016 & 7 \\
Flexible HR practice & 2016 & 9 \\
Flexible complexity management and engineering by innovative services & 2014 & 8
\end{tabular}

*To be published in November 2021

**To be published in March 2022

through h-index. The top publishing developed countries based on cite ratio (citations per paper) are France, UK, Denmark, Austria, USA, Australia, and Germany. The top publishing emerging countries include Russia, India, and Malaysia. In general, these top publishing developed countries have an average cite ratio of 16 , whereas the top publishing emerging countries have an average cite ratio of 11. This indicates that the articles from the top publishing developed countries have fetched more citations as compared to the articles published from the emerging countries.

Table 20 (in appendix) classifies all the publishing countries into different geographical regions for 2000-2020, 2011-2015, and 2016-2020. Figure 8 presents the percentage representation of countries in different geographies that are publishing in GJFSM. The contributing countries are from across the globe, i.e., Asia (44\%),
Europe (36\%), Africa (6\%), North America (6\%), South America (4\%), and Pacific (4\%). This points toward the global authorship base of the Journal.

Bibliographic coupling occurs when two articles commonly cite the third article. The analysis of countries is also performed through bibliographic coupling. Figure 9 represents countries' bibliographic coupling with a threshold of a minimum 1 citation and minimum 3 documents. Out of 52 countries, 25 countries meet the threshold criteria. In Fig. 9, nodes represent the most influential countries, and links represent the coupling between them. India is at the center of the graph. In the series of country coupling, the coupling strength of India and USA is highest followed by India and UK, India and Canada, and India and France. The coupling linkages can also be seen for UK and Spain, 
Table 4 Top ten publishing countries according to cite ratio

\begin{tabular}{lllllc}
\hline Rank & Country & TP & TC & TC/TP & h-index \\
\hline 1 & France & 4 & 113 & 28.3 & 21.4 \\
2 & UK & 8 & 171 & 17 & 4 \\
3 & Denmark & 4 & 68 & 13 & 5 \\
4 & Austria & 8 & 511 & 12.5 & 11 \\
5 & USA & 41 & 48 & 12 & 3 \\
6 & Russia & 4 & 119 & 10.8 & 7 \\
7 & Australia & 11 & 2684 & 10.7 & 24 \\
8 & India & 250 & 53 & 10.6 & 3 \\
9 & Malaysia & 5 & 40 & 10 & 4 \\
\hline
\end{tabular}

\section{Percentage Representation of Countries}

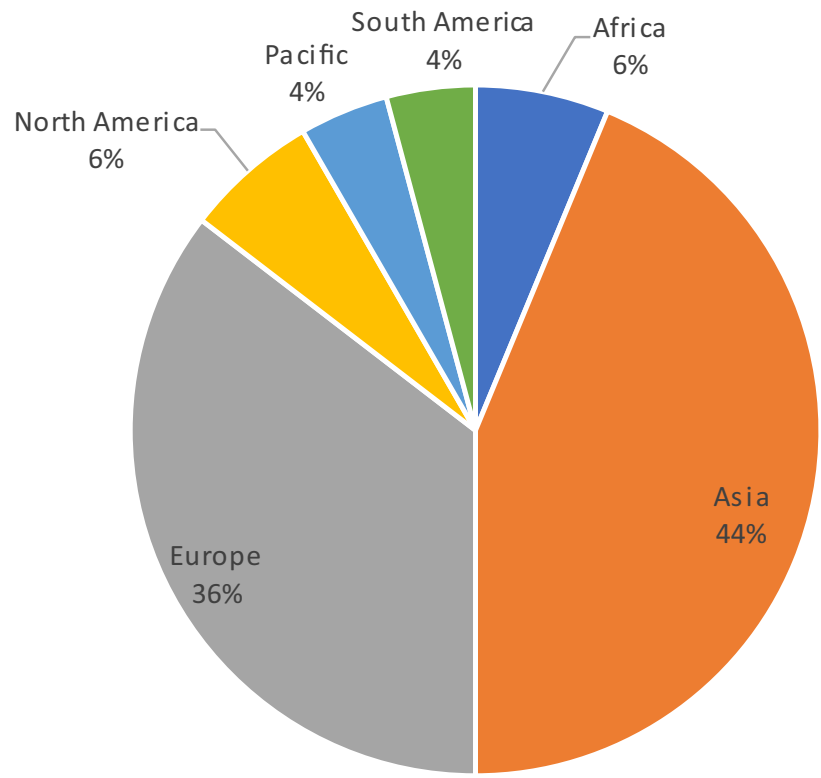

Fig. 8 Geography-wise representation of countries published in GJFSM

France and Spain, Canada and United Arab Emirates, and Bangladesh and Australia.

\section{Top Citing Countries of GJFSM}

Table 5 lists the top citing countries with at least 20 articles citing GJFSM. The top citing countries include India, the USA, and the UK, followed by China and Australia.

Further, the countries are classified into different geographical regions (Appendix Table 21), and geographywise percentage representation of countries citing GJFSM is highlighted (Fig. 10). The top citing countries are from Europe (35\%), Asia (33\%), Africa (15\%), North America $(8 \%)$, South America (6\%), and Pacific (3\%). The analysis indicates that GJFSM has received citations from all the regions portraying its global readership and impact.

\section{Citing Journals Analysis}

Table 6 highlights the top 10 citing journals of GJFSM with at least 20 citations. The top citing Journals include "Benchmarking," "Journal of Cleaner Production," and "International Journal of Production Research." Table 22 (in appendix) classifies the top citing journals of GJFSM. The classification is performed based on the Scopus category. The list is sorted according to the number of articles in each source. The top categorizations of the articles are from "strategy and management" (19.20\%), followed by "business and international management" (7.23\%), and "general business, management, and accounting" (6.94\%) (Fig. 11). The citation profile of GJFSM exhibits that it impacted a variety of areas from Management, Engineering, and Social Sciences, demonstrating its broader impact. The total number of journals citing GJFSM is 657, and the total number of citing articles is 2047 during 2000 to 2020.

Further, GJFSM publications are categorized into five different types of flexibility, i.e., strategic flexibility, manufacturing flexibility, supply chain flexibility, marketing flexibility, and financial flexibility. The articles in respective flexibility types are analyzed to understand the key citing journals in each area. Table 7 lists the top five citing journals of GJFSM in each flexibility classification.

\section{Keywords and Co-citation Analysis}

\section{Keywords Analysis}

The keywords analysis was performed to analyze the most influential keywords. The evolution of the top 10 keywords 


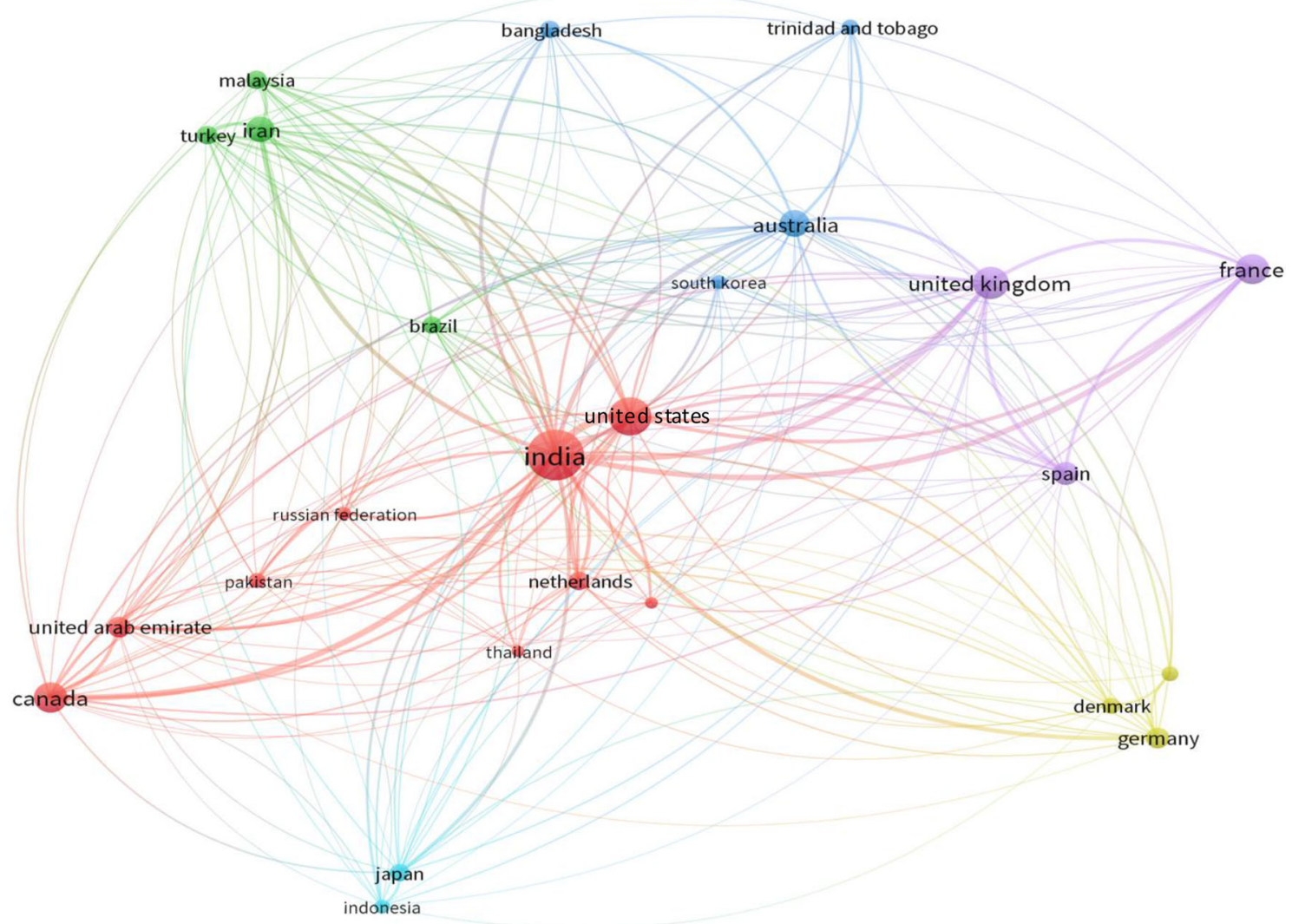

Fig. 9 Country coupling

is mapped in Table 8. It highlights that the major focus area of the Journal is flexibility since its inception. In the 2000-2005 time period, the Journal was more oriented toward productivity, competitive advantage, competitiveness, and innovation. From 2006 to 2010, the orientation was shifted toward manufacturing flexibility and competitiveness. In the 2011-2015 time period, the Journal was oriented toward manufacturing flexibility, cloud computing, and innovation. In the 2016-2020 time period, the Journal has oriented toward IT flexibility, supply chain flexibility, and firm performance.

The keyword co-occurrences analysis is performed to monitor the emerging fields and research themes. Figure 12 presents keyword co-occurrences network of articles published between 2000 and 2020. A threshold of minimum 3 occurrences of keywords was applied. Out of 1502 keywords, 94 meet the threshold criteria. The duplications and not connected items were removed. Thus, the final number of keywords used in the analysis is 85 . The top keywords in the co-occurrences network are flexibility, competitiveness, supply chain management, strategic flexibility, and flexible manufacturing system. The flexibility is also related to real-option, advanced manufacturing technology, and knowledge management. However, minimal studies are conducted in these domains.

\section{Co-citation Analysis}

Co-citation analysis was performed to understand the Journal's intellectual structure. It was performed using VOS viewer. The threshold criteria of a minimum number of citations of a cited reference were applied to 6 . Out of 18,611 citations, 70 citations meet the threshold. Further, the duplicities among the clusters were removed. Thus, the final analysis was performed on 65 references. Seven clusters were identified. However, due to the presence of only two articles in cluster 7, this cluster was removed from the analysis. The results of the co-citation analysis are presented in Table 9 and Fig. 13.

Cluster 1 is dominated by the work related to Strategic Flexibility. The major themes discussed in this cluster are resource flexibility, strategic intent, organizational process, user participation, external flexibility, technical flexibility, valuation of flexibility, financial flexibility, and continuitychange. Cluster 2 highlights the work related to Мапиfacturing Flexibility. It consists of the keywords including machine flexibility, routing flexibility, planning, design, control strategies, integrated manufacturing, system improvement, modification flexibility, new product flexibility, labor flexibility, and material handling flexibility. 
Table 5 Top citing countries of GJFSM

\begin{tabular}{ll}
\hline Country & Total articles citing GJFSM \\
\hline India & 954 \\
USA & 232 \\
UK & 170 \\
China & 157 \\
Australia & 91 \\
Iran & 75 \\
Malaysia & 71 \\
Brazil & 56 \\
France & 52 \\
Spain & 49 \\
UAE & 47 \\
Canada & 46 \\
Germany & 46 \\
Taiwan & 44 \\
Pakistan & 36 \\
Saudi Arabia & 35 \\
South Africa & 34 \\
Turkey & 33 \\
Denmark & 32 \\
Italy & 32 \\
Bangladesh & 28 \\
Thailand & 27 \\
Indonesia & 25 \\
Netherlands & 25 \\
Sweden & 25 \\
Hong Kong &
\end{tabular}

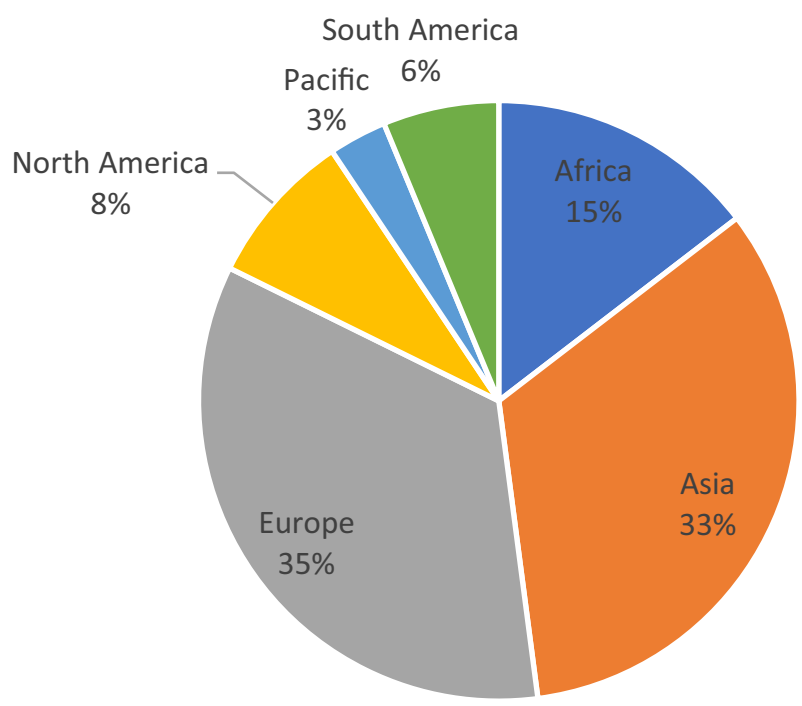

Fig. 10 Geography-wise representation of countries citing GJFSM
Cluster 3 is dominated by the work related to Conceptual Frameworks of Flexibility. The major themes discussed in this cluster are environment uncertainty, expansion, volume, mix, new product, modification, expansion, and flexibility hierarchy. Cluster 4 highlights the work related to Supply Chain Flexibility. It consists of the keywords including uncertainty management, demand, cost, volume, product specifications, on-time delivery, supplier flexibility, operational performance, logistics optimization, and supply chain design. Cluster 5 is dominated by the work related to Modeling Flexibility. The major themes discussed in this cluster are the analytic hierarchy process, structural equation modeling, multiobjective linear programming, integer linear programming, continuity-change matrix, interpretive matrix, partial least squares method, and interpretive ranking process. Cluster 6 highlights the work in the area of Application of TISM. It consists of the keywords including modified-TISM, fuzzyTISM, continuity and change, humanitarian supply chain, flexible control system, and flexible manufacturing dimensions.

\section{Comparative Standing of Journals in Different Flexibility Areas}

Flexibility is defined as "the ability of a firm to reallocate and reconfigure its organizational resources, processes, and strategies to deal with environmental changes" (Zhou \& $\mathrm{Wu}, 2010$, p. 449). The key flexibility themes published in GJFSM include strategic flexibility, manufacturing flexibility, supply chain flexibility, organizational flexibility, information systems flexibility, marketing flexibility, and financial flexibility. The top journals publishing these works were identified from the year 2000 to 2020. The top journals were identified based on the highest total publications in the respective areas of flexibility. The Scopus search was performed in abstract-title-keyword. The filters such as subject area: business, management and accounting, source type: Journal, and language: English were applied.

\section{Flexibility}

The keyword search of flexibility was performed. Table 10 lists the top journals in the area of flexibility. The top publishing journals of flexibility include the "International Journal of Production Research," “International Journal of Production Economics," and "Global Journal of Flexible Systems Management." However, GJFSM publishes around $51.18 \%$ of the total articles published in GJFSM that directly include the term flexibility in article title, abstract, or keywords. GJFSM has been publishing reviews 
Table 6 Top ten citing journals of GJFSM (excluding self-citation of GJFSM)

\begin{tabular}{llc}
\hline Rank & Journal & Total citations \\
\hline 1 & Benchmarking & 69 \\
2 & Journal of Cleaner Production & 55 \\
3 & International Journal of Production Research & 40 \\
4 & Sustainability Switzerland & 35 \\
5 & Production Planning and Control & 32 \\
6 & International Journal of Productivity and Performance Management & 26 \\
7 & Annals of Operations Research & 24 \\
8 & International Journal of Production Economics & 23 \\
9 & Journal of Manufacturing Technology Management & 21 \\
10 & International Journal of Services and Operations Management & 20 \\
11 & Journal of Modeling in Management & 20 \\
\hline
\end{tabular}

Fig. 11 Category-wise citing article analysis

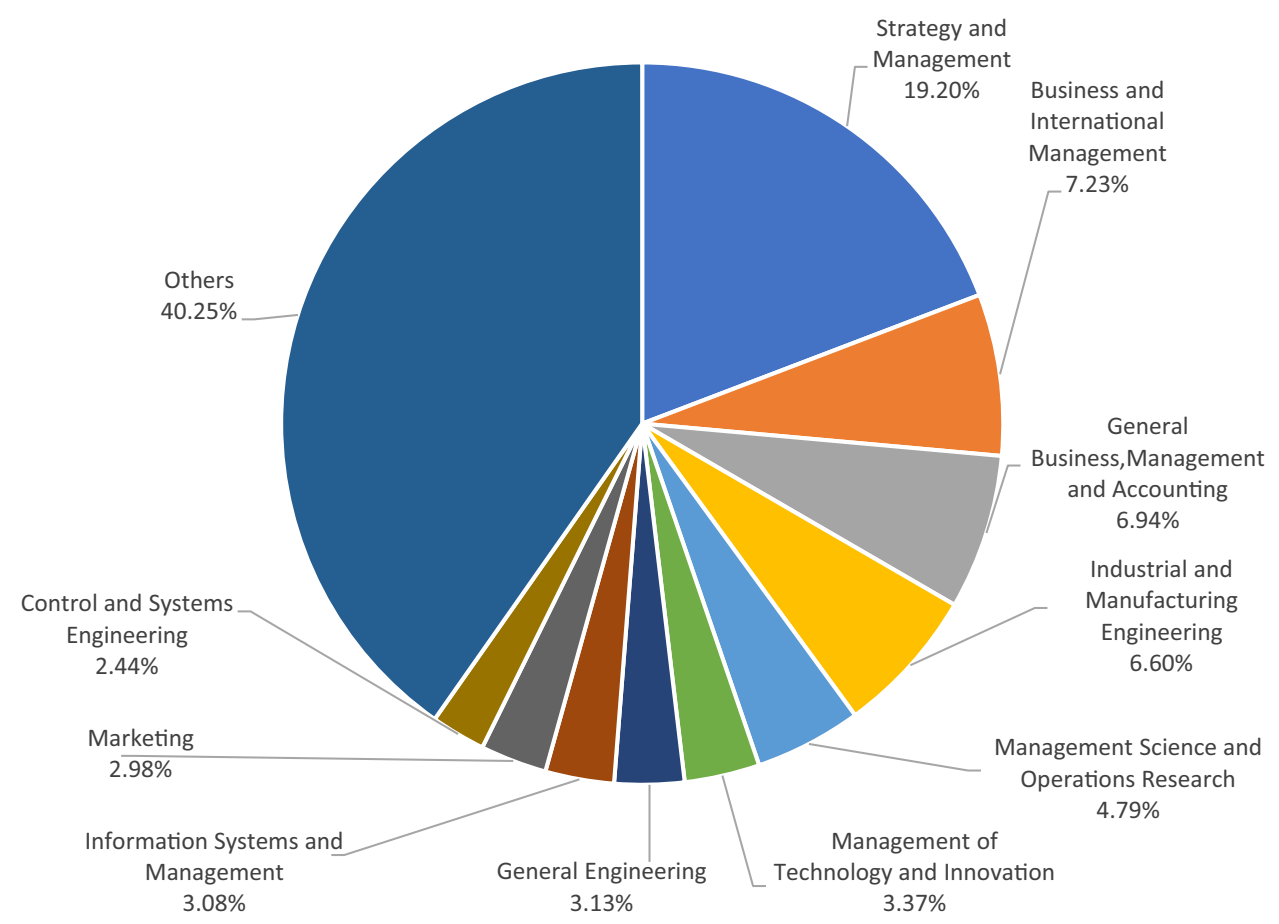

on flexibility from time to time (Sharma et al., 2010; Shukla et al., 2019).

\section{Strategic Flexibility}

The top journals in the area of strategic flexibility are presented in Table 11. The top publishing journals of strategic flexibility include "Global Journal of Flexible Systems Management," "International Journal of Technology Management," and "Strategic Management Journal." GJFSM has the highest publications in strategic flexibility and also publishes around $5.40 \%$ of the total articles published in GJFSM that directly include strategic flexibility or related terms in article title, abstract, or keywords. A review on strategic flexibility was published at an early stage by Roberts and Stockport (2009).

\section{Manufacturing Flexibility}

The Scopus search was performed based on terms manufacturing flexibility or flexible manufacturing. Table 12 lists the top journals in the area of manufacturing flexibility. The top publishing journals of manufacturing flexibility include the "International Journal of Production Research," "International Journal of Production Economics," "Journal of Manufacturing Technology 
Table 7 List of top journals citing GJFSM articles on strategic flexibility, manufacturing flexibility, supply chain flexibility, marketing flexibility, and financial flexibility

\begin{tabular}{|c|c|c|c|c|}
\hline \multicolumn{5}{|l|}{ Top Journals } \\
\hline Strategic flexibility & $\begin{array}{l}\text { Manufacturing } \\
\text { flexibility }\end{array}$ & Supply chain flexibility & Marketing flexibility & Financial flexibility \\
\hline Journal of Business Research & Benchmarking & Journal of Cleaner Production & $\begin{array}{l}\text { International Journal of } \\
\text { Information Management }\end{array}$ & The Flexible Enterprise* \\
\hline Sustainability Switzerland & $\begin{array}{l}\text { International } \\
\text { Journal of } \\
\text { Production } \\
\text { Research }\end{array}$ & Benchmarking & Information Systems Frontiers & $\begin{array}{l}\text { Journal of Strategic } \\
\text { Marketing }\end{array}$ \\
\hline $\begin{array}{l}\text { Industrial Marketing } \\
\text { Management }\end{array}$ & $\begin{array}{l}\text { International } \\
\text { Journal of } \\
\text { Systems } \\
\text { Assurance } \\
\text { Engineering } \\
\text { and } \\
\text { Management }\end{array}$ & $\begin{array}{l}\text { International Journal of } \\
\text { Production Research }\end{array}$ & Journal of Strategic Marketing & $\begin{array}{l}\text { Organizational Flexibility and } \\
\text { Competitiveness }\end{array}$ \\
\hline $\begin{array}{l}\text { International Journal of } \\
\text { Production Economics }\end{array}$ & $\begin{array}{l}\text { Journal of } \\
\text { Cleaner } \\
\text { Production }\end{array}$ & $\begin{array}{l}\text { Annals of Operations } \\
\text { Research }\end{array}$ & Management Decision & $\begin{array}{l}\text { Business Process } \\
\text { Management Journal }\end{array}$ \\
\hline $\begin{array}{l}\text { International Business } \\
\text { Review }\end{array}$ & $\begin{array}{l}\text { International } \\
\text { Journal of } \\
\text { Productivity } \\
\text { and } \\
\text { Performance } \\
\text { Management }\end{array}$ & $\begin{array}{l}\text { International Journal of } \\
\text { Production Economics }\end{array}$ & $\begin{array}{l}\text { Advances in Intelligent } \\
\text { Systems and Computing }\end{array}$ & $\begin{array}{l}\text { Corporate Ownership and } \\
\text { Control }\end{array}$ \\
\hline
\end{tabular}

* Book

Table 8 Evolution of top keywords in GJFSM

\begin{tabular}{llll}
\hline 2016-2020 & 2011-2015 & 2006-2010 & $2000-2005$ \\
\hline Flexibility & Flexibility & Flexibility & Flexibility \\
Supply chain & Flexible manufacturing system & Strategic flexibility & Productivity \\
Agility & Risk & Competitiveness & Competitive advantage \\
Big data & SAP-LAP & Flexible manufacturing system & Competitiveness \\
Case study & TISM & Change management & Core competence \\
Manufacturing flexibility & Cloud computing & Manufacturing flexibility & Innovation \\
Supply chain flexibility & Collaboration & System dynamics & Management \\
TISM & Green supply chain & Advanced manufacturing technology & Sustainable competitive advantage \\
Corporate governance & Innovation & Areas of change & Strategic flexibility \\
Firm performance & Lean manufacturing & Biotech startup & Conceptual framework \\
\hline
\end{tabular}

Management," and "Global Journal of Flexible Systems Management." Although the GJFSM does not have the highest publications in manufacturing flexibility, it publishes around $19.44 \%$ of the total articles published in GJFSM that directly include the term manufacturing flexibility or related issues in article title, abstract, or keywords. Reviews on manufacturing flexibility have also appeared in GJFSM, such as Sharma and Sushil (2002) and Mishra et al. (2014).

\section{Supply Chain Flexibility}

To analyze the consolidated stream of research on supply chain flexibility, keyword search was performed for terms 


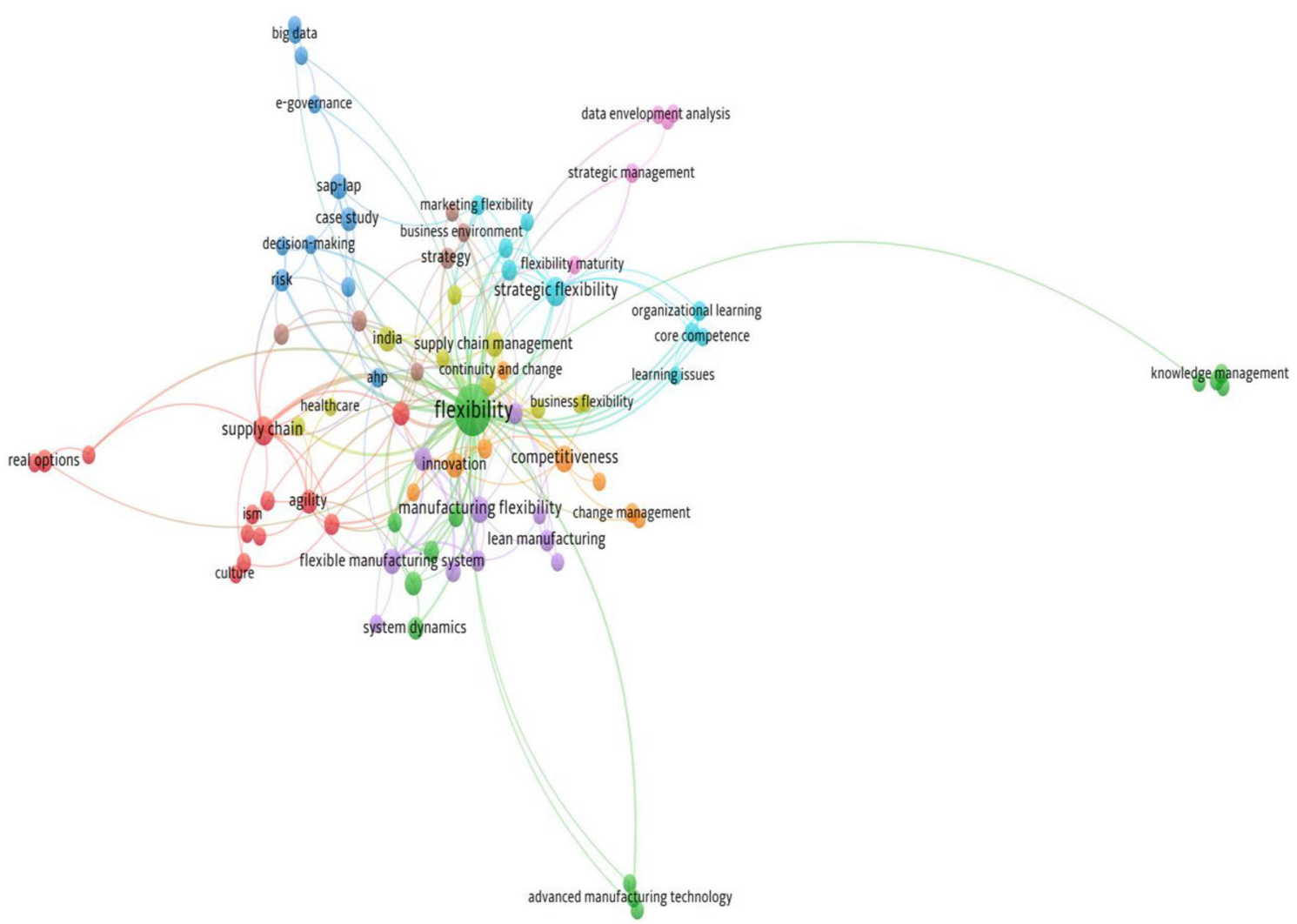

Fig. 12 Keyword co-occurrences

supply chain flexibility or flexible supply chain. Table 13 lists the top journals in the area of supply chain flexibility. The top publishing journals of supply chain flexibility include the "International Journal of Production Research," "International Journal of Production Economics," and "Global Journal of Flexible Systems Management." Although the GJFSM does not have the highest publications in supply chain flexibility, it publishes around $14.90 \%$ of the total articles published in GJFSM that directly include the term supply chain flexibility or related issues in article title, abstract, or keywords. A systematic literature review on manufacturing and supply chain flexibility was published by Pérez-Pérez et al. (2019), which placed GJFSM at rank number five.

\section{Organizational Flexibility}

A keyword search was performed based on the term organizational flexibility. Table 14 shows the top journals in the area of organizational flexibility. The top publishing journals of organizational flexibility include "Global Journal of Flexible Systems Management," "International Journal of Human Resource Management," and "International Journal of Operations and Production
Management." GJFSM has the highest publications in organizational flexibility and also publishes around $21.38 \%$ of the total articles published in GJFSM that directly include organizational flexibility or related terms in article title, abstract, or keywords.

\section{Information Systems Flexibility}

The keyword search was performed based on the term information systems flexibility or IT flexibility. Table 15 lists the top journals in the area of information systems flexibility. The top publishing journals of information systems flexibility include the "International Journal of Production Research," "Global Journal of Flexible Systems Management," and "Decision Support Systems." Although the GJFSM does not have the highest publications in information systems flexibility, it publishes around $6.48 \%$ of the total articles published in GJFSM that directly include information system flexibility or related terms in article title, abstract, or keywords. 
Table 9 Co-citation clusters

\begin{tabular}{|c|c|c|c|}
\hline & Cluster 1 & Cluster 2 & Cluster 3 \\
\hline Academic field & Strategic flexibility & Manufacturing flexibility & Conceptual frameworks of flexibility \\
\hline Major themes & $\begin{array}{l}\text { Resource flexibility; } \\
\text { Strategic intent; } \\
\text { Organizational process; } \\
\text { User participation; } \\
\text { External Flexibility; } \\
\text { Technical Flexibility; } \\
\text { Valuation of flexibility; } \\
\text { Financial flexibility; } \\
\text { Continuity-change }\end{array}$ & $\begin{array}{l}\text { Routing flexibility; } \\
\text { Planning, design, and control strategies; } \\
\text { Integrated manufacturing; } \\
\text { System improvement; } \\
\text { Labor flexibility; } \\
\text { Material handling flexibility; } \\
\text { New product flexibility; } \\
\text { Modification flexibility; } \\
\text { Machine flexibility }\end{array}$ & $\begin{array}{l}\text { Environment uncertainty; } \\
\text { Expansion; } \\
\text { Volume; } \\
\text { Mix; } \\
\text { New product; } \\
\text { Modification; } \\
\text { Expansion; } \\
\text { Flexibility hierarchy }\end{array}$ \\
\hline Academic field & $\begin{array}{l}\text { Cluster } 4 \\
\text { Supply chain flexibility }\end{array}$ & $\begin{array}{l}\text { Cluster } 5 \\
\text { Modeling flexibility }\end{array}$ & $\begin{array}{l}\text { Cluster } 6 \\
\text { Application of TISM }\end{array}$ \\
\hline Major themes & $\begin{array}{l}\text { Uncertainty management; } \\
\text { Demand; } \\
\text { Cost; } \\
\text { Volume; } \\
\text { Product specifications; } \\
\text { On-time delivery; } \\
\text { Supplier flexibility; } \\
\text { Operational performance; } \\
\text { Logistics optimization; } \\
\text { Supply chain design }\end{array}$ & $\begin{array}{l}\text { Analytical hierarchy process; } \\
\text { Structural equation modeling; } \\
\text { Multiobjective linear programming; } \\
\text { Integer linear programming; } \\
\text { Continuity-Change matrix; } \\
\text { Interpretive matrix; } \\
\text { Partial least squares method; } \\
\text { Interpretive ranking process }\end{array}$ & $\begin{array}{l}\text { Modified-TISM; } \\
\text { Fuzzy-TISM; } \\
\text { Continuity and change; } \\
\text { Humanitarian supply chain; } \\
\text { Flexible control system; } \\
\text { Flexible manufacturing dimensions }\end{array}$ \\
\hline
\end{tabular}

\section{Marketing Flexibility}

The keyword search was performed based on term marketing flexibility. Table 16 lists the top journals in the area of marketing flexibility. The top publishing journals of marketing flexibility include "Industrial Marketing Management," "Management Science," and "Global Journal of Flexible Systems Management." Although the GJFSM does not have the highest publications in marketing flexibility, it publishes around $3.67 \%$ of the total articles published in GJFSM that directly include the term marketing flexibility or related issues in article title, abstract, or keywords.

\section{Financial Flexibility}

To analyze the consolidated stream of research on financial flexibility, keyword research was performed for term financial flexibility. Table 17 lists the top journals in the area of financial flexibility. The top publishing journals of financial flexibility include "Global Journal of Flexible Systems Management," "Journal of Corporate Finance," and "International Journal of Production Economics." GJFSM has highest publications in financial flexibility and also publishes around $3.89 \%$ of the total articles published in GJFSM that directly include financial flexibility or related terms in article title, abstract, or keywords.

\section{Discussion on Flexibility Research}

The flexibility research has been published in extant literature at the generic level and in specific areas such as strategic flexibility, organizational flexibility, manufacturing flexibility, and so on. The GJFSM has published papers in the last two decades in all the significant categories of flexibility. The ranking of GJFSM as per the number of articles published and the percentage of total publications is summarized in Table 18. It can be observed from Table 18 that GJFSM lies in the top three/four journals as per the number of papers published and is also ranked as number one in some areas such as strategic flexibility, organizational flexibility, and financial flexibility. As per the percentage of total papers published, it is ranked as number one in all the categories. It is gratifying to note that 


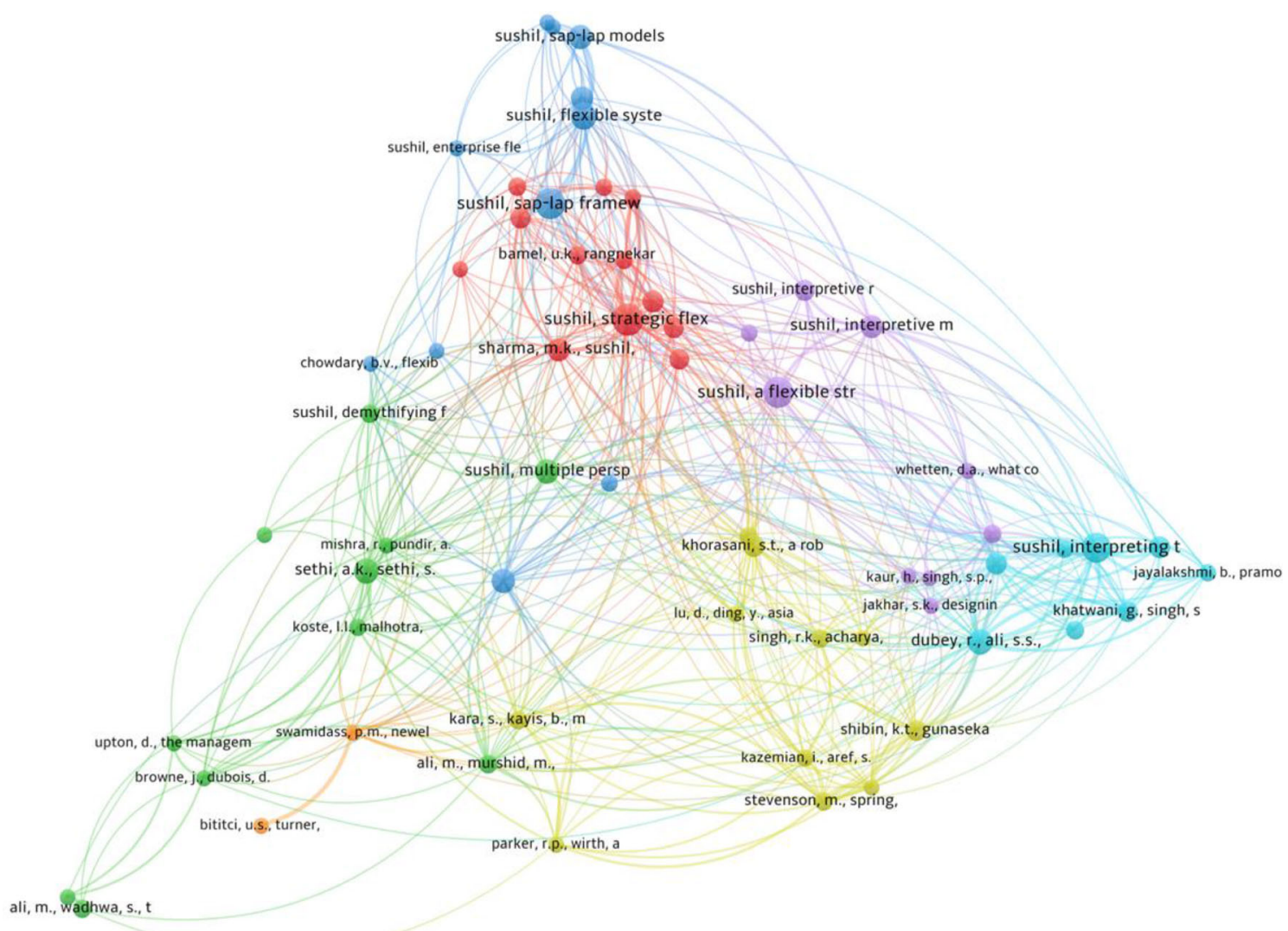

Fig. 13 Co-citation graph

Table 10 Top journals of flexibility (2000-2020)

\begin{tabular}{llllr}
\hline Rank & Journal & $\begin{array}{l}\text { Publications on } \\
\text { flexibility }\end{array}$ & $\begin{array}{l}\text { Total } \\
\text { Publications }\end{array}$ & $\begin{array}{l}\text { Percentage publication on flexibility } \\
(\%)\end{array}$ \\
\hline 1 & International Journal of Production Research & 441 & 7718 & 5.71 \\
2 & International Journal of Production Economics & 275 & 5636 & 4.87 \\
3 & Global Journal of Flexible Systems Management & 237 & 463 & 51.18 \\
4 & Journal of Cleaner Production & 222 & 22,545 & 0.98 \\
5 & Journal of Contextual Behavioral Science & 147 & 444 & 33.10 \\
6 & Management Science & 109 & 3597 & 3.03 \\
7 & International Journal of Operations and Production & 103 & 1410 & 7.30 \\
& $\quad$ Management & & & 3.14 \\
9 & International Journal of Human Resource Management & 91 & 2897 & 8.17 \\
10 & Journal of Manufacturing Technology Management & 89 & 1090 & 1824 \\
\hline
\end{tabular}

GJFSM being a focused journal on flexibility, the percentage of papers published in various types is reasonably high in contrast to the other journals that give limited space for the flexibility-related articles. In some journals, the percentage is five to six percent, but in most of the journals, it is within one percent.
A low percentage of flexibility research in most of the journals, published in various functional areas, indicates that most of the journals are publishing flexibility research but allocate a limited space to such papers. The significant contributions in these journals are made in the primary line research on the respective functional areas. The journals in the operations management area, such as the International 
Table 11 Top ten journals of strategic flexibility (2000-2020)

\begin{tabular}{lllll}
\hline Rank & Journal & $\begin{array}{l}\text { Publications on strategic } \\
\text { flexibility }\end{array}$ & $\begin{array}{l}\text { Total } \\
\text { publications }\end{array}$ & $\begin{array}{l}\text { Percentage publication on strategic } \\
\text { flexibility }(\%)\end{array}$ \\
\hline 1 & Global Journal of Flexible Systems Management & 25 & 463 & 5.40 \\
2 & International Journal of Technology Management & 12 & 1517 & 0.79 \\
3 & Strategic Management Journal & 8 & 1936 & 0.41 \\
4 & International Journal of Production Economics & 7 & 5636 & 0.12 \\
5 & European Journal of Marketing & 6 & 1528 & 0.39 \\
6 & Industrial Marketing Management & 6 & 2585 & 0.23 \\
7 & Journal of Business Research & 6 & 6016 & 0.10 \\
8 & Strategic Direction & 5 & 2969 & 0.17 \\
9 & International Journal of Operations and Production & 4 & 1410 & 0.28 \\
10 & $\quad$ Management & & 371 & 1.08 \\
\hline
\end{tabular}

Table 12 Top ten journals of manufacturing flexibility (2000-2020)

\begin{tabular}{llllc}
\hline Rank & Journal & $\begin{array}{l}\text { Publications on } \\
\text { manufacturing flexibility }\end{array}$ & $\begin{array}{l}\text { Total } \\
\text { publications }\end{array}$ & $\begin{array}{l}\text { Percentage publication on } \\
\text { manufacturing flexibility }(\%)\end{array}$ \\
\hline 1 & International Journal of Production Research & 579 & 7718 & 7.50 \\
2 & International Journal of Production Economics & 191 & 5636 & 3.39 \\
3 & Journal of Manufacturing Technology Management & 111 & 1090 & 10.18 \\
4 & Global Journal of Flexible Systems Management & 90 & 463 & 19.44 \\
5 & Production Planning and Control & 78 & 1824 & 4.28 \\
6 & Journal of Manufacturing Processes & 77 & 2540 & 3.03 \\
7 & International Journal of Operations and Production & 73 & 1410 & 5.18 \\
8 & $\quad$ Management & 61 & 22,545 & 0.27 \\
9 & Journal of Cleaner Production & & 891 & 5.61 \\
10 & International Journal of Manufacturing Technology & 50 & & 2.25 \\
\hline
\end{tabular}

Journal of Production Research, International Journal of Production Economics, Journal of Manufacturing Technology Management, and International Journal of Supply Chain Management, have given a reasonable emphasis on reporting flexibility research. Though some journals have not appeared in the top ten journals in respective categories, occasional publications on flexibility have appeared in these journals such as Long Range Planning (Eppink, 1978; Volberda, 1997); Journal of Management Studies (Dai et al., 2018; Evans, 1991); Organization Science (Eisenhardt et al., 2010; Volberda, 1996; Young-Ybarra \& Wiersema, 1999); Journal of International Business
Studies (Allen \& Pantzalis, 1996); Operations Research (Huchzermeier \& Cohen, 1996); California Management Review (Bahrami \& Evans, 2011; Upton, 1994); Academy of Management Perspectives (Hitt et al., 1998; Shimizu \& Hitt, 2004); European Journal of Operational Research (Beach et al., 2000); Omega (Bengtsson \& Olhager, 2002); Academy of Management Journal (Nadkarni \& Herrmann, 2010); Decision Sciences (Yu et al., 2013); International Journal of Management Reviews (Brozovic, 2018); Business Strategy and the Environment (Perez-Valls et al. 2016); Strategic Entrepreneurship Journal (Brinckmann et al., 2019); British Journal of Management (Dalziel, 
Table 13 Top journals of supply chain flexibility (2000-2020)

\begin{tabular}{|c|c|c|c|c|}
\hline Rank & Journal & $\begin{array}{l}\text { Publications on supply chain } \\
\text { flexibility }\end{array}$ & $\begin{array}{l}\text { Total } \\
\text { publications }\end{array}$ & $\begin{array}{l}\text { Percentage publication on supply chain } \\
\text { flexibility }(\%)\end{array}$ \\
\hline 1 & International Journal of Production Research & 146 & 7718 & 1.89 \\
\hline 2 & International Journal of Production Economics & 137 & 5636 & 2.43 \\
\hline 3 & Global Journal of Flexible Systems Management & 69 & 463 & 14.90 \\
\hline 4 & $\begin{array}{l}\text { International Journal of Supply Chain } \\
\text { Management }\end{array}$ & 61 & 2045 & 2.98 \\
\hline 5 & Supply Chain Management & 53 & 833 & 6.36 \\
\hline 6 & Production Planning and Control & 39 & 1824 & 2.14 \\
\hline 7 & $\begin{array}{l}\text { Journal of Manufacturing Technology } \\
\text { Management }\end{array}$ & 37 & 1090 & 3.39 \\
\hline 8 & Journal of Cleaner Production & 32 & 22,545 & 0.14 \\
\hline 9 & $\begin{array}{l}\text { International Journal of Operations and } \\
\text { Production Management }\end{array}$ & 29 & 1410 & 2.06 \\
\hline 10 & International Journal of Logistics Management & 27 & 616 & 4.38 \\
\hline
\end{tabular}

Table 14 Top journals of organizational flexibility (2000-2020)

\begin{tabular}{|c|c|c|c|c|}
\hline Rank & Journal & $\begin{array}{l}\text { Publications on } \\
\text { organizational flexibility }\end{array}$ & $\begin{array}{l}\text { Total } \\
\text { publications }\end{array}$ & $\begin{array}{l}\text { Percentage publication on } \\
\text { organizational flexibility ( } \%)\end{array}$ \\
\hline 1 & Global Journal of Flexible Systems Management & 99 & 463 & 21.38 \\
\hline 2 & $\begin{array}{l}\text { International Journal of Human Resource } \\
\text { Management }\end{array}$ & 52 & 2897 & 1.79 \\
\hline 3 & $\begin{array}{l}\text { International Journal of Operations and } \\
\text { Production Management }\end{array}$ & 42 & 1410 & 2.98 \\
\hline 4 & International Journal of Production Economics & 40 & 5636 & 0.71 \\
\hline 5 & International Journal of Production Research & 36 & 7718 & 0.47 \\
\hline 6 & $\begin{array}{l}\text { Human Resource Management International } \\
\text { Digest }\end{array}$ & 33 & 2222 & 1.49 \\
\hline 7 & Personnel Review & 31 & 1238 & 2.50 \\
\hline 8 & Management Decision & 30 & 2406 & 1.25 \\
\hline 9 & $\begin{array}{l}\text { Journal of Manufacturing Technology } \\
\text { Management }\end{array}$ & 27 & 1090 & 2.48 \\
\hline 10 & Journal of Operations Management & 26 & 894 & 2.91 \\
\hline
\end{tabular}

2009; Hatum \& Pettigrew, 2006; Herhausen et al., 2021); Ecology and Society (Olsson et al., 2006), and so on. Thus it can be observed that a variety of leading journals have published flexibility research in the past, but sporadically. It can be concluded that flexibility is a general management concept, and researchers from different functional backgrounds can aspire to publish in a range of leading journals. However, GJFSM appears to be emerging as a lead journal exclusively covering the whole gamut of the flexibility areas, and flexibility researchers can aspire to publish cross-functional flexibility research in this growing Journal focused on flexibility and related issues.

Though GJFSM has been publishing in almost all areas of flexibility, the total representation is comparatively less in marketing flexibility and financial flexibility. Some important cross-functional flexibility papers in GJFSM are by Flaherty et al. (2015), Birasnav et al. (2015), and Dey et al. (2019). It is expected to enhance cross-functional 
Table 15 Top journals of information systems flexibility (2000-2020)

\begin{tabular}{|c|c|c|c|c|}
\hline Rank & Journal & $\begin{array}{l}\text { Publications on information } \\
\text { systems flexibility }\end{array}$ & $\begin{array}{l}\text { Total } \\
\text { publications }\end{array}$ & $\begin{array}{l}\text { Percentage publication on information } \\
\text { systems flexibility }(\%)\end{array}$ \\
\hline 1 & $\begin{array}{l}\text { International Journal of Production } \\
\text { Research }\end{array}$ & 48 & 7718 & 0.62 \\
\hline 2 & $\begin{array}{l}\text { Global Journal of Flexible Systems } \\
\text { Management }\end{array}$ & 30 & 463 & 6.48 \\
\hline 3 & Decision Support Systems & 25 & 2627 & 0.95 \\
\hline 4 & Journal of Cleaner Production & 19 & 22,545 & 0.08 \\
\hline 5 & $\begin{array}{l}\text { Journal of Management Information } \\
\text { Systems }\end{array}$ & 19 & 946 & 2.01 \\
\hline 6 & Knowledge Based Systems & 16 & 4352 & 0.37 \\
\hline 7 & $\begin{array}{l}\text { International Journal of Production } \\
\text { Economics }\end{array}$ & 16 & 5636 & 0.28 \\
\hline 8 & $\begin{array}{l}\text { Industrial Management and Data } \\
\text { Systems }\end{array}$ & 13 & 1559 & 0.83 \\
\hline 9 & Production Planning and Control & 13 & 1824 & 0.71 \\
\hline 10 & $\begin{array}{l}\text { Journal of Enterprise Information } \\
\text { Management }\end{array}$ & 12 & 817 & 1.47 \\
\hline
\end{tabular}

Table 16 Top journals of marketing flexibility (2000-2020)

\begin{tabular}{|c|c|c|c|c|}
\hline Rank & Journal & $\begin{array}{l}\text { Publications on marketing } \\
\text { flexibility }\end{array}$ & $\begin{array}{l}\text { Total } \\
\text { publications }\end{array}$ & $\begin{array}{l}\text { Percentage publication on marketing } \\
\text { flexibility }(\%)\end{array}$ \\
\hline 1 & Industrial Marketing Management & 18 & 2585 & 0.70 \\
\hline 2 & Management Science & 18 & 3597 & 0.50 \\
\hline 3 & $\begin{array}{l}\text { Global Journal of Flexible Systems } \\
\text { Management }\end{array}$ & 17 & 463 & 3.67 \\
\hline 4 & $\begin{array}{l}\text { Journal of Business and Industrial } \\
\text { Marketing }\end{array}$ & 15 & 1387 & 1.08 \\
\hline 5 & $\begin{array}{l}\text { International Journal of Production } \\
\text { Economics }\end{array}$ & 13 & 5636 & 0.23 \\
\hline 6 & Marketing Science & 12 & 1178 & 1.02 \\
\hline 7 & Journal of Marketing & 11 & 952 & 1.16 \\
\hline 8 & International Marketing Review & 10 & 814 & 1.23 \\
\hline 9 & European Journal of Marketing & 9 & 1528 & 0.59 \\
\hline 10 & $\begin{array}{l}\text { Journal of Manufacturing Technology } \\
\text { Management }\end{array}$ & 9 & 1090 & 0.83 \\
\hline
\end{tabular}

flexibility research to evolve a sound theory of flexibility. GJFSM has also published works that relate to multiple connotations of flexibility. Some recent contributions are related to agility (Khorasani, 2018; Piya et al., 2020; Vaishnavi \& Suresh, 2020); resilience (Kumar \& Anbanandam, 2020); disruption (Aldrighetti et al., 2019); inclusion (Malik et al., 2019); emergency management
(Ha, 2019); ambidexterity (Katic \& Agarwal, 2018); rapid alignment (Razzak et al., 2018); the speed of adjustment (Warmana et al., 2020); responsiveness (Singla \& Singh, 2018); super-flexibility (Evans \& Bahrami, 2020), and so on. The application areas are also becoming more integrative such as sustainability, Industry 4.0, big data analytics, health care, competitiveness, disaster management, 
Table 17 Top journals of financial flexibility (2000-2020)

\begin{tabular}{|c|c|c|c|c|}
\hline Rank & Journal & $\begin{array}{l}\text { Publications on financial } \\
\text { flexibility }\end{array}$ & $\begin{array}{l}\text { Total } \\
\text { publications }\end{array}$ & $\begin{array}{l}\text { Percentage publication on financial } \\
\text { flexibility }(\%)\end{array}$ \\
\hline 1 & $\begin{array}{l}\text { Global Journal of Flexible Systems } \\
\text { Management }\end{array}$ & 18 & 463 & 3.89 \\
\hline 2 & Journal of Corporate Finance & 17 & 1,630 & 1.04 \\
\hline 3 & $\begin{array}{l}\text { International Journal of Production } \\
\text { Economics }\end{array}$ & 16 & 5,636 & 0.28 \\
\hline 4 & Review of Financial Studies & 14 & 1,739 & 0.81 \\
\hline 5 & Management Science & 12 & 3,597 & 0.33 \\
\hline 6 & Journal of Financial Economics & 11 & 2,168 & 0.51 \\
\hline 7 & Managerial Finance & 11 & 1,474 & 0.75 \\
\hline 8 & Financial Management & 9 & 637 & 1.41 \\
\hline 9 & Journal of Business Research & 8 & 6,016 & 0.13 \\
\hline 10 & Journal of Cleaner Production & 8 & 22,545 & 0.04 \\
\hline
\end{tabular}

Table 18 GJFSM ranking in different flexibility areas

\begin{tabular}{lll}
\hline Flexibility areas & $\begin{array}{l}\text { Rank by total number of paper (total } \\
\text { publications) }\end{array}$ & $\begin{array}{l}\text { Rank by percentage publication (actual percentage } \\
\text { publication) }\end{array}$ \\
\hline Flexibility & $3(237)$ & $1(51.18 \%)$ \\
Strategic flexibility & $1(25)$ & $1(5.40 \%)$ \\
Organizational flexibility & $1(99)$ & $1(21.38 \%)$ \\
Manufacturing flexibility & $4(90)$ & $1(19.44 \%)$ \\
Supply chain flexibility & $3(69)$ & $1(14.90 \%)$ \\
Information systems & $2(30)$ & $1(6.48 \%)$ \\
$\quad$ flexibility & $3(17)$ & $1(3.67 \%)$ \\
Marketing flexibility & $1(18)$ & $1(3.89 \%)$ \\
Financial flexibility & &
\end{tabular}

COVID-19, and many more emerging areas related to flexibility. Thus, the authors can also explore multiple connotations of flexibility in cutting-edge research areas in GJFSM.

\section{Conclusion and way forward}

In 2020, GJFSM completed two decades of its publication. This study provides a comprehensive view of the GJFSM's evolution and growth trajectory between 2000 and 2020. The study provides an insight into the publication trend, citation structure, most contributing countries, citing journals, citing countries, special issues of GJFSM, keyword co-occurrences, co-citation analysis, and top journals in different domains of flexibility.

Initially, in 2000 the Journal published 8 articles that is treated as the incubation period for the Journal. A growth of around $350 \%$ is observed from 2000 to 2020 . The citations of the Journal have an increasing trend from the year 2017. In 2020, the total citations of the Journal were 1033. Also, around $90.84 \%$ of the articles are at least cited once. The top publishing countries were sorted through the cite ratio. The most influential country with highest cite ratio was found to be France, followed by the UK and Denmark. The contributors are from across the globe, i.e., North America, South America, Africa, Asia, Europe, and the Pacific. The co-citation analysis has classified the Journal's papers into six broad categories. They include 
strategic flexibility, manufacturing flexibility, the conceptual framework of flexibility, supply chain flexibility, modeling flexibility, and the application of TISM.

Over the years, GJFSM has established itself as an essential journal in flexibility research. It is one of the top journals that publishes in diverse areas of flexibility such as information systems flexibility, organizational flexibility, manufacturing flexibility, supply chain flexibility, marketing flexibility, financial flexibility, and strategic flexibility. Despite publishing on numerous flexibility topics, GJFSM is oriented toward publishing works in the areas of crossfunctional flexibility. It is aspired to lead the Journal to mature with more cross-functional flexibility research to address the contemporary and integrative application areas rather than functional flexibility alone. Further, diverse connotations and frameworks of flexibility, systematic and thematic reviews, meta-analysis, and novel methodologies would be the way forward for this evolving lead journal in flexibility research.

\section{Appendix}

See Tables 19, 20, 21, and 22.

Table 19 Citation structure of GJFSM

\begin{tabular}{|c|c|c|c|c|c|}
\hline \multirow[t]{2}{*}{ Years } & \multicolumn{3}{|c|}{ Number of articles having citations } & \multirow[t]{2}{*}{$\mathrm{TP}$} & \multirow[t]{2}{*}{ h-index } \\
\hline & $\geq 20$ & $\geq 10$ & $\geq 1$ & & \\
\hline 2000 & 0 & 0 & 4 & 5 & 1 \\
\hline 2001 & 1 & 4 & 17 & 20 & 6 \\
\hline 2002 & 2 & 6 & 12 & 13 & 7 \\
\hline 2003 & 3 & 4 & 11 & 13 & 6 \\
\hline 2004 & 2 & 5 & 10 & 12 & 6 \\
\hline 2005 & 2 & 6 & 15 & 15 & 7 \\
\hline 2006 & 0 & 4 & 10 & 11 & 6 \\
\hline 2007 & 0 & 2 & 12 & 14 & 5 \\
\hline 2008 & 1 & 4 & 13 & 15 & 4 \\
\hline 2009 & 2 & 5 & 19 & 20 & 8 \\
\hline 2010 & 1 & 1 & 17 & 18 & 6 \\
\hline 2011 & 1 & 2 & 11 & 12 & 4 \\
\hline 2012 & 3 & 11 & 17 & 20 & 10 \\
\hline 2013 & 5 & 11 & 20 & 20 & 10 \\
\hline 2014 & 11 & 17 & 25 & 28 & 12 \\
\hline 2015 & 6 & 12 & 25 & 25 & 11 \\
\hline 2016 & 6 & 11 & 24 & 26 & 10 \\
\hline 2017 & 4 & 11 & 24 & 24 & 11 \\
\hline 2018 & 3 & 10 & 27 & 27 & 10 \\
\hline 2019 & 1 & 10 & 24 & 27 & 10 \\
\hline 2020 & 0 & 1 & 20 & 28 & 5 \\
\hline Total & 54 & 137 & 357 & 393 & Overall \\
\hline$\%$ & $13.74 \%$ & $34.86 \%$ & $90.84 \%$ & $100 \%$ & h-index $=33$ \\
\hline
\end{tabular}

Editorials and notes are excluded for the analysis 
Table 20 Classification of contributing countries to GJFSM

\begin{tabular}{|c|c|c|c|}
\hline \multirow[t]{2}{*}{ Continent } & \multicolumn{3}{|l|}{ Countries } \\
\hline & $2000-20$ & 2011-2015 & 2016-2020 \\
\hline \multirow[t]{3}{*}{ Africa } & Nigeria & - & Nigeria \\
\hline & South Africa & & South Africa \\
\hline & Tunisia & & Tunisia \\
\hline \multirow[t]{21}{*}{ Asia } & Bangladesh & Hong Kong & Bangladesh \\
\hline & China & India & China \\
\hline & Hong Kong & Indonesia & India \\
\hline & India & Iran & Indonesia \\
\hline & Indonesia & Japan & Iran \\
\hline & Iran & Malaysia & Japan \\
\hline & Israel & Pakistan & Jordan \\
\hline & Japan & Thailand & Malaysia \\
\hline & Jordan & Vietnam & Oman \\
\hline & Kazakhstan & & Pakistan \\
\hline & Malaysia & & Qatar \\
\hline & Oman & & Saudi Arabia \\
\hline & Pakistan & & South Korea \\
\hline & Qatar & & Thailand \\
\hline & Saudi Arabia & & Turkey \\
\hline & South Korea & & UAE \\
\hline & Taiwan & & Vietnam \\
\hline & Thailand & & \\
\hline & Turkey & & \\
\hline & UAE & & \\
\hline & Vietnam & & \\
\hline \multirow[t]{17}{*}{ Europe } & Austria & Austria & Denmark \\
\hline & Czech Republic & Czech Republic & Finland \\
\hline & Denmark & Germany & France \\
\hline & Finland & Ireland & Germany \\
\hline & France & Luxembourg & Hungary \\
\hline & Germany & Russian Federation & Ireland \\
\hline & Hungary & Slovakia & Italy \\
\hline & Ireland & Spain & $\begin{array}{l}\text { Russian } \\
\text { Federation }\end{array}$ \\
\hline & Italy & Sweden & Spain \\
\hline & Luxembourg & & Switzerland \\
\hline & Netherlands & & UK \\
\hline & Russian Federation & & \\
\hline & Slovakia & & \\
\hline & Spain & & \\
\hline & Sweden & & \\
\hline & Switzerland & & \\
\hline & UK & & \\
\hline \multirow{3}{*}{$\begin{array}{l}\text { North } \\
\text { America }\end{array}$} & Canada & Canada & Canada \\
\hline & $\begin{array}{c}\text { Trinidad and } \\
\text { Tobago }\end{array}$ & $\begin{array}{c}\text { Trinidad and } \\
\text { Tobago }\end{array}$ & USA \\
\hline & USA & USA & \\
\hline \multirow[t]{2}{*}{ Pacific } & Australia & Australia & Australia \\
\hline & New Zealand & & New Zealand \\
\hline \multirow{2}{*}{$\begin{array}{l}\text { South } \\
\text { America }\end{array}$} & Brazil & - & Brazil \\
\hline & Chile & & Chile \\
\hline
\end{tabular}

Table 21 Classification of countries citing GJFSM

\begin{tabular}{|c|c|c|c|}
\hline \multirow{2}{*}{ Continent } & \multicolumn{3}{|l|}{ Countries } \\
\hline & $2000-2020$ & $2011-2015$ & 2016-2020 \\
\hline \multirow[t]{14}{*}{ Africa } & Algeria & Algeria & Algeria \\
\hline & Cameroon & Kenya & Cameroon \\
\hline & Egypt & Morocco & Egypt \\
\hline & Ethiopia & South Africa & Ghana \\
\hline & Ghana & Tunisia & Morocco \\
\hline & Kenya & & Nigeria \\
\hline & Morocco & & Sudan \\
\hline & Nigeria & & Swaziland \\
\hline & South Africa & & Tanzania \\
\hline & Sudan & & Tunisia \\
\hline & Swaziland & & Uganda \\
\hline & Tanzania & & \\
\hline & Tunisia & & \\
\hline & Uganda & & \\
\hline \multirow[t]{32}{*}{ Asia } & Bahrain & China & Bahrain \\
\hline & Bangladesh & Hong Kong & Bangladesh \\
\hline & China & India & China \\
\hline & Cyprus & Indonesia & Cyprus \\
\hline & Hong Kong & Iran & Hong Kong \\
\hline & India & Israel & India \\
\hline & Indonesia & Japan & Indonesia \\
\hline & Iran & Jordan & Iran \\
\hline & Iraq & Kuwait & Iraq \\
\hline & Israel & Lebanon & Israel \\
\hline & Japan & Malaysia & Japan \\
\hline & Jordan & Oman & Jordan \\
\hline & Kazakhstan & Pakistan & Kazakhstan \\
\hline & Kuwait & Qatar & Kuwait \\
\hline & Lebanon & Saudi Arabia & Lebanon \\
\hline & Macao & Singapore & Macao \\
\hline & Malaysia & South Korea & Malaysia \\
\hline & Nepal & Taiwan & Nepal \\
\hline & Oman & Thailand & Oman \\
\hline & Pakistan & Turkey & Pakistan \\
\hline & Palestine & UAE & Palestine \\
\hline & Philippines & Vietnam & Philippines \\
\hline & Qatar & & Qatar \\
\hline & Saudi Arabia & & Saudi Arabia \\
\hline & Singapore & & Singapore \\
\hline & South Korea & & South Korea \\
\hline & Taiwan & & Taiwan \\
\hline & Thailand & & Thailand \\
\hline & Turkey & & Turkey \\
\hline & UAE & & UAE \\
\hline & Vietnam & & Vietnam \\
\hline & Yemen & & Yemen \\
\hline
\end{tabular}


Table 21 continued

\begin{tabular}{|c|c|c|c|}
\hline \multirow[t]{2}{*}{ Continent } & \multicolumn{3}{|l|}{ Countries } \\
\hline & 2000-2020 & $2011-2015$ & 2016-2020 \\
\hline \multirow[t]{33}{*}{ Europe } & Austria & Austria & Austria \\
\hline & Belgium & Belgium & Belgium Cameroon \\
\hline & Bulgaria & Czech Republic & Bulgaria \\
\hline & Croatia & Denmark & Croatia \\
\hline & Czech Republic & Estonia & Czech Republic \\
\hline & Denmark & Finland & Denmark \\
\hline & Estonia & France & Estonia \\
\hline & Finland & Germany & Finland \\
\hline & France & Greece & France \\
\hline & Germany & Ireland & Germany \\
\hline & Greece & Italy & Greece \\
\hline & Hungary & Liechtenstein & Hungary \\
\hline & Ireland & Lithuania & Ireland \\
\hline & Italy & Luxembourg & Italy \\
\hline & Liechtenstein & Netherlands & Liechtenstein \\
\hline & Lithuania & Norway & Lithuania \\
\hline & Luxembourg & Poland & Luxembourg \\
\hline & Montenegro & Portugal & Montenegro \\
\hline & Netherlands & Romania & Netherlands \\
\hline & North Macedonia & Russian Federation & North Macedonia \\
\hline & Norway & Serbia & Norway \\
\hline & Poland & Slovakia & Poland \\
\hline & Portugal & Spain & Portugal \\
\hline & Romania & Sweden & Romania \\
\hline & Russian Federation & Switzerland & Russian Federation \\
\hline & Serbia & UK & Serbia \\
\hline & Slovakia & & Slovakia \\
\hline & Slovenia & & Spain \\
\hline & Spain & & Sweden \\
\hline & Sweden & & Switzerland \\
\hline & Switzerland & & Ukraine \\
\hline & Ukraine & & UK \\
\hline & UK & & \\
\hline \multirow[t]{8}{*}{ North America } & Canada & Canada & Canada \\
\hline & Cuba & Honduras & Cuba \\
\hline & Honduras & Mexico & Jamaica \\
\hline & Jamaica & Trinidad and Tobago & Mexico \\
\hline & Mexico & USA & Puerto Rico \\
\hline & Puerto Rico & & Trinidad and Tobago \\
\hline & Trinidad and Tobago & & USA \\
\hline & USA & & \\
\hline \multirow[t]{3}{*}{ Pacific } & Australia & Australia & Australia \\
\hline & New Zealand & New Zealand & New Zealand \\
\hline & Papua New Guinea & & Papua New Guinea \\
\hline \multirow[t]{6}{*}{ South America } & Brazil & Brazil & Brazil \\
\hline & Chile & Peru & Chile \\
\hline & Colombia & Uruguay & Colombia \\
\hline & Ecuador & & Ecuador \\
\hline & Peru & & Peru \\
\hline & Uruguay & & \\
\hline
\end{tabular}

Table 22 Classification and number of top citing journals and articles of GJFSM (Compiled from: Scopus)

\begin{tabular}{|c|c|c|}
\hline Classification of Journal (as per Scopus) & $\begin{array}{l}\text { No. of } \\
\text { journals }\end{array}$ & $\begin{array}{l}\text { No. of } \\
\text { articles }\end{array}$ \\
\hline Strategy and Management & 32 & 393 \\
\hline Business and International Management & 40 & 148 \\
\hline $\begin{array}{l}\text { General Business, Management and } \\
\text { Accounting }\end{array}$ & 29 & 142 \\
\hline Industrial and Manufacturing Engineering & 29 & 135 \\
\hline $\begin{array}{l}\text { Management Science and Operations } \\
\text { Research }\end{array}$ & 20 & 98 \\
\hline Management of Technology and Innovation & 23 & 69 \\
\hline General Engineering & 26 & 64 \\
\hline Information Systems and Management & 17 & 63 \\
\hline Marketing & 26 & 61 \\
\hline Control and Systems Engineering & 7 & 50 \\
\hline Economics and Econometrics & 22 & 43 \\
\hline Information Systems & 16 & 41 \\
\hline $\begin{array}{l}\text { Organizational Behavior and Human } \\
\text { Resource Management }\end{array}$ & 17 & 36 \\
\hline General Decision Sciences & 9 & 33 \\
\hline Education & 19 & 32 \\
\hline Computer Science Applications & 15 & 29 \\
\hline Management, Monitoring, Policy and Law & 7 & 25 \\
\hline Safety, Risk, Reliability and Quality & 7 & 23 \\
\hline $\begin{array}{l}\text { Business, Management and Accounting } \\
\text { (miscellaneous) }\end{array}$ & 11 & 21 \\
\hline General Computer Science & 11 & 20 \\
\hline Software & 10 & 18 \\
\hline Transportation & 5 & 18 \\
\hline Environmental Engineering & 5 & 18 \\
\hline Management Information Systems & 8 & 15 \\
\hline Artificial Intelligence & 7 & 15 \\
\hline Finance & 10 & 14 \\
\hline General Social Sciences & 11 & 12 \\
\hline $\begin{array}{l}\text { General Business, Management and } \\
\text { Accounting }\end{array}$ & 10 & 12 \\
\hline Library and Information Sciences & 8 & 12 \\
\hline Statistics, Probability and Uncertainty & 4 & 12 \\
\hline Multidisciplinary & 8 & 11 \\
\hline Geography, Planning and Development & 9 & 10 \\
\hline Health Policy & 6 & 10 \\
\hline Public Administration & 4 & 10 \\
\hline Sociology and Political Science & 7 & 9 \\
\hline Computer Networks and Communications & 7 & 8 \\
\hline Modeling and Simulation & 6 & 8 \\
\hline Mechanical Engineering & 6 & 8 \\
\hline Civil and Structural Engineering & 6 & 8 \\
\hline Industrial Relations & 5 & 8 \\
\hline Building and Construction & 5 & 7 \\
\hline $\begin{array}{l}\text { Economics, Econometrics and Finance } \\
\text { (miscellaneous) }\end{array}$ & 4 & 7 \\
\hline
\end{tabular}


Table 22 continued

\begin{tabular}{lll}
\hline Classification of Journal (as per Scopus) & $\begin{array}{l}\text { No. of } \\
\text { journals }\end{array}$ & $\begin{array}{l}\text { No. of } \\
\text { articles }\end{array}$ \\
\hline $\begin{array}{l}\text { General Economics, Econometrics and } \\
\quad \text { Finance }\end{array}$ & 6 & 6 \\
$\begin{array}{l}\text { Tourism, Leisure and Hospitality } \\
\quad \text { Management }\end{array}$ & 4 & 5 \\
Pollution & 4 & 5 \\
Architecture & 4 & 5 \\
General Chemical Engineering & 4 & 4 \\
Applied Mathematics & 4 & 4 \\
Others & 97 & 242 \\
Total & 657 & 2047 \\
\hline
\end{tabular}

Funding The author(s) received no financial support for the research, authorship, and/or publication of this article.

\section{Declarations}

Conflict of interest The authors declare that they have no conflict of interest.

Ethical approval This study used bibliometric data and did not involve any human or animal subjects.

\section{References}

Aldrighetti, R., Zennaro, I., Finco, S., \& Battini, D. (2019). Healthcare supply chain simulation with disruption considerations: A case study from Northern Italy. Global Journal of Flexible Systems Management, 20(Suppl 1), S81-S102.

Allen, L., \& Pantzalis, C. (1996). Valuation of the operating flexibility of multinational corporations. Journal of International Business Studies, 27(4), 633-653.

Aria, M., \& Cuccurullo, C. (2017). Bibliometrix: An R-tool for comprehensive science mapping analysis. Journal of Informetrics, 11(4), 959-975.

Bahrami, H., \& Evans, S. (2011). Super-flexibility for real-time adaptation: Perspectives from silicon valley. California Management Review, 53(3), 21-39.

Bartol, T., Budimir, G., Dekleva-Smrekar, D., Pusnik, M., \& Juznic, P. (2014). Assessment of research fields in Scopus and web of science in the view of national research evaluation in Slovenia. Scientometrics, 98(2), 1491-1504.

Beach, R., Muhlemann, A. P., Price, D. H. R., Paterson, A., \& Sharp, J. A. (2000). A review of manufacturing flexibility. European Journal of Operational Research, 122(1), 41-57.

Bengtsson, J., \& Olhager, J. (2002). The impact of the product mix on the value of flexibility. Omega, 30(4), 265-273.

Birasnav, M., Mittal, R., \& Loughlin, S. (2015). Linking leadership behaviors and information exchange to improve supply chain performance: A conceptual model. Global Journal of Flexible Systems Management, 16(2), 205-217.

Brinckmann, J., Villanueva, J., Grichnik, D., \& Singh, L. (2019). Sources of strategic flexibility in new ventures: An analysis of the role of resource leveraging practices. Strategic Entrepreneurship Journal, 13(2), 154-178.
Broadus, R. N. (1987). Toward a definition of "bibliometrics." Scientometrics, 12(5-6), 373-379.

Brozovic, D. (2018). Strategic flexibility: A review of the literature. International Journal of Management Reviews, 20(1), 3-31.

Crane, D. (1972). Invisible colleges: Diffusion of knowledge in scientific communication. University of Chicago Press.

Dai, Y., Goodale, J. C., Byun, G., \& Ding, F. (2018). Strategic flexibility in new high-technology ventures. Journal of Management Studies, 55(2), 265-294.

Dalziel, M. (2009). Forgoing the flexibility of real options: When and why firms commit to investment decisions. British Journal of Management, 20(3), 401-412.

Dey, S., Sharma, R. R. K., \& Pandey, B. K. (2019). Relationship of manufacturing flexibility with organizational strategy. Global Journal of Flexible Systems Management, 20(3), 237-256.

Diodato, V. (1994). Dictionary of bibliometrics. Haworth Press.

Dixit, S., Singh, S., Dhir, S., \& Dhir, S. (2021). Antecedents of strategic thinking and its impact on competitive advantage. Journal of Indian Business Research. https://doi.org/10.1108/ JIBR-08-2020-0262 (article-in-press).

Donthu, N., Kumar, S., \& Pattnaik, D. (2020). Forty-five years of journal of business research: A bibliometric analysis. Journal of Business Research, 109(1), 1-14.

Eisenhardt, K. M., Furr, N. R., \& Bingham, C. B. (2010). CROSSROADS-Microfoundations of performance: Balancing efficiency and flexibility in dynamic environments. Organization Science, 21(6), 1263-1273.

Eppink, D. J. (1978). Planning for strategic flexibility. Long Range Planning, 11(4), 9-15.

Evans, J. S. (1991). Strategic flexibility for high technology maneuvers: A conceptual framework. Journal of Management Studies, 28(1), 69-89.

Evans, S., \& Bahrami, H. (2020). Super-flexibility in practice: Insights from a crisis. Global Journal of Flexible Systems Management, 21(3), 207-214.

Flaherty, S., Rosecky, R., Hillard, J., \& Singer, D. (2015). The impact of cash flow and debt on organizational agility. Global Journal of Flexible Systems Management, 16(2), 133-143.

Ha, K. M. (2019). Suggesting a "Three-Ball cycle" theory on international emergency management and its application in Korea. Global Journal of Flexible Systems Management, 20(1), 91-102.

Hatum, A., \& Pettigrew, A. M. (2006). Determinants of organizational flexibility: A study in an emerging economy. British Journal of Management, 17(2), 115-137.

Herhausen, D., Morgan, R. E., Brozović, D., \& Volberda, H. W. (2021). Re-examining strategic flexibility: A meta-analysis of its antecedents, consequences and contingencies. British Journal of Management, 32(2), 435-455.

Hitt, M. A., Keats, B. W., \& DeMarie, S. M. (1998). Navigating in the new competitive landscape: Building strategic flexibility and competitive advantage in the 21 st century. Academy of Management Perspectives, 12(4), 22-42.

Huchzermeier, A., \& Cohen, M. A. (1996). Valuing operational flexibility under exchange rate risk. Operations Research, 44(1), $100-113$.

Janen, T. (2020). A comparison study of the top five journals on human resource management indexed with Scopus. In: 3rd Research conference on business studies (pp. 186-193)

Katic, M., \& Agarwal, R. (2018). The flexibility paradox: Achieving ambidexterity in high-variety, low-volume manufacturing. Global Journal of Flexible Systems Management, 19(Suppl 1), S69-S86.

Kessler, M. M. (1963). Bibliographic coupling between scientific papers. American Documentation, 14(1), 10-25. 
Khorasani, S. T. (2018). A robust optimization model for supply chain in agile and flexible mode based on variables of uncertainty. Global Journal of Flexible Systems Management, 19(3), 239-253.

Kumar, P. S., \& Anbanandam, R. (2020). Theory building on supply chain resilience: A SAP-LAP analysis. Global Journal of Flexible Systems Management, 21(2), 113-133.

Lummus, R. R., Duclos, L. K., \& Vokurka, R. J. (2003). Supply chain flexibility: Building a new model. Global Journal of Flexible Systems Management, 4(4), 1-13.

Malik, S., Maheshwari, G. C., \& Singh, A. (2019). Understanding financial inclusion in India: A theoretical framework building through SAP-LAP and efficient IRP. Global Journal of Flexible Systems Management, 20(2), 117-140.

Merigó, J. M., Muller, C., Modak, N. M., \& Laengle, S. (2019). Research in production and operations management: A university-based bibliometric analysis. Global Journal of Flexible Systems Management, 20(1), 1-29.

Mishra, R., Pundir, A. K., \& Ganapathy, L. (2014). Manufacturing flexibility research: A review of literature and agenda for future research. Global Journal of Flexible Systems Management, 15(2), 101-112.

Nadkarni, S., \& Herrmann, P. O. L. (2010). CEO personality, strategic flexibility, and firm performance: The case of the Indian business process outsourcing industry. Academy of Management Journal, 53(5), 1050-1073.

Olsson, P., Gunderson, L. H., Carpenter, S. R., Ryan, P., Lebel, L., Folke, C., \& Holling, C. S. (2006). Shooting the rapids: Navigating transitions to adaptive governance of social-ecological systems. Ecology and Society, 11(1), 1-21.

Pérez-Pérez, M., Kocabasoglu-Hillmer, C., Serrano-Bedia, A. M., \& López-Fernández, M. C. (2019). Manufacturing and supply chain flexibility: Building an integrative conceptual model through systematic literature review and bibliometric analysis. Global Journal of Flexible Systems Management, 20(Suppl 1), $\mathrm{S} 1-\mathrm{S} 23$.

Perez-Valls, M., Cespedes-Lorente, J., \& Moreno-Garcia, J. (2016). Green practices and organizational design as sources of strategic flexibility and performance. Business Strategy and the Environment, 25(8), 529-544.

Pitt, C., Park, A., \& McCarthy, I. P. (2021). A bibliographic analysis of 20 years of research on innovation and new product development in technology and innovation management (TIM) journals. Journal of Engineering and Technology Management, 61(1), 101632.

Piya, S., Shamsuzzoha, A., Khadem, M., \& Al-Hinai, N. (2020). Identification of critical factors and their interrelationships to design agile supply chain: Special focus to oil and gas industries. Global Journal of Flexible Systems Management, 21(3), 263-281.

Rajan, R., Dhir, S., \& Sushil. . (2020). Alliance termination research: A bibliometric review and research agenda. Journal of Strategy and Management, 13(3), 351-375.

Razzak, M. A., Al-Kwifi, O. S., \& Ahmed, Z. U. (2018). Rapid alignment of resources and capabilities in time-bound networks: A theoretical proposition. Global Journal of Flexible Systems Management, 19(4), 273-287.

Roberts, N., \& Stockport, G. J. (2009). Defining strategic flexibility. Global Journal of Flexible Systems Management, 10(1), 27-32.

Seebacher, G., \& Winkler, H. (2013). A citation analysis of the research on manufacturing and supply chain flexibility. International Journal of Production Research, 51(11), 3415-3427.

Sharma, M. K., Sushil, \& Jain, P. K. (2010). Revisiting flexibility in organizations: exploring its impact on performance. Global Journal of Flexible Systems Management, 11(3), 51-68.
Sharma, O. P., \& Sushil (2002). Issues in managing manufacturing flexibility: A review. Global Journal of Flexible Systems Management, 3(2\&3), 11-30.

Shimizu, K., \& Hitt, M. A. (2004). Strategic flexibility: Organizational preparedness to reverse ineffective strategic decisions. Academy of Management Perspectives, 18(4), 44-59.

Shukla, S. K., Sushil, \& Sharma, M. K. (2019). Managerial paradox toward flexibility: Emergent views using thematic analysis of literature. Global Journal of Flexible Systems Management, 20(4), 349-370.

Singh, S., \& Dhir, S. (2019). Structured review using TCCM and bibliometric analysis of international cause-related marketing, social marketing, and innovation of the firm. International Review on Public and Nonprofit Marketing, 16(2), 335-347.

Singh, S., Akbani, I., \& Dhir, S. (2020a). Service innovation implementation: A systematic review and research agenda. The Service Industries Journal, 40(7-8), 491-517.

Singh, S., Dhir, S., Das, V. M., \& Sharma, A. (2020). Bibliometric overview of the technological forecasting and social change journal: analysis from 1970 to 2018. Technological Forecasting and Social Change, 154(1), 119963.

Singh, S., Paul, J., \& Dhir, S. (2021). Innovation implementation in Asia-Pacific countries: A review and research agenda. Asia Pacific Business Review, 27(2), 180-208.

Singla, M., \& Singh, S. (2018). Impact of institutional set-up on the responsiveness to change in a firm's governance structure: A comparative study of public and private sector enterprises in India. Global Journal of Flexible Systems Management, 19(2), $159-172$.

Small, H. (1973). Co-citation in the scientific literature: A new measure of the relationship between two documents. Journal of the American Society for Information Science, 24(4), 265-269.

Srivastava, S., Singh, S., \& Dhir, S. (2020). Culture and International business research: A review and research agenda. International Business Review, 29(4), 101709.

Sushil (2000). Genesis, launch and innovative features. Global Journal of Flexible Systems Management, 1(1), 3-4.

Sushil (2012). Multiple perspective of flexible systems management. Global Journal of Flexible Systems Management, 13(1), 1-2.

Tsay, M. Y. (2009). Citation analysis of Ted Nelson's works and his influence on hypertext concept. Scientometrics, 79(3), 451-472.

Upton, D. M. (1994). The Management of Manufacturing Flexibility. California Management Review, 36(2), 72-89. Winter.

Vaishnavi, V., \& Suresh, M. (2020). Assessing the readiness level of healthcare for implementing agility using fuzzy logic approach. Global Journal of Flexible Systems Management, 21(2), 163-189.

Volberda, H. W. (1996). Toward the flexible form: How to remain vital in hypercompetitive environments. Organization Science, 7(4), 359-374.

Volberda, H. W. (1997). Building flexible organization for fast moving markets. Long Range Planning, 30(2), 169-183.

Warmana, G. O., Rahyuda, I. K., Purbawangsa, I. B. A., \& Artini, N. L. G. S. (2020). Investigating capital structure speed of adjustment (SOA) of Indonesian companies for corporate value. Global Journal of Flexible Systems Management, 21(3), 215-231.

Young-Ybarra, C., \& Wiersema, M. (1999). Strategic flexibility in information technology alliances: The influence of transaction cost economics and social exchange theory. Organization Science, 10(4), 439-459.

Yu, K., Cadeaux, J., \& Song, H. (2013). Distribution channel network and relational performance: The intervening mechanism of adaptive distribution flexibility. Decision Sciences, 44(5), 915-950. 
Zhou, K. Z., \& Wu, F. (2010). Technological capability, strategic flexibility, and product innovation. Strategic Management Journal, 31(5), 547-561.

\section{Key Questions}

1. What are the key flexibility areas published in GJFSM?

2. How can bibliometric analysis be performed for analyzing any Journal?

Publisher's Note Springer Nature remains neutral with regard to jurisdictional claims in published maps and institutional affiliations.

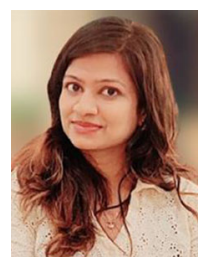

Shiwangi Singh is a research scholar in Strategic Management Area at the Department of Management Studies (DMS), IIT Delhi. She is gold medallist during her studies in graduation and post-graduation. Her research papers were selected for presentations at various research conferences like PANIIT International Management Conference (PANIITIMC), Academy of International Business (AIB) India Chapter, Academy for Global Business Advancement (AGBA), and Strategic Management Society (SMS). She has published several research papers in leading international journals including Technological Forecasting and Social Change, Asia Pacific Business Review, and International Business Review. Her area of research is the strategic management, innovation, implementation of innovation, and start-ups.

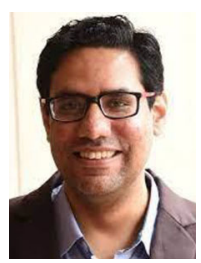

Sanjay Dhir is an Associate professor in Strategic Management Area at Department of Management Studies (DMS), IIT Delhi. He is a Fellow (Ph.D.) from the Indian Institute of Management (IIM) Lucknow. He worked at corporate sectorMahindra and Mahindra Ltd (Automotive), R\&D Department, Nasik-for three and a half years. He has published several research papers in leading international journals including case studies at Richard Ivey School of Business, Western Ontario jointly distributed by Ivey and Harvard Business School, Journal of Business Research, Technological Forecasting and Social Change, and International Business Review. His research papers were presented and published as conference proceedings at several prestigious academic conferences such as Academy of Management (AoM), Academy of International Business (AIB), Strategic Management Society (SMS), Southern Management Association (SMA), International Simulation Conference of India (ISCI, IIT Mumbai) and Strategic Management Forum (SMF, IIM Lucknow). His research interests include strategic management, joint ventures, innovation management, management of change, implementation strategies, and international strategy.

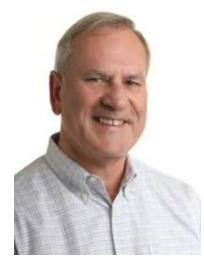

Stuart Evans is a Distinguished Service Professor at the Integrated Innovation Institute and Director of the Emirates-CMU i-Lab at Carnegie Mellon University (Silicon Valley Campus). His research focuses on how enterprises adapt to disruptive technologies. His professional career spans research (SRI International and the Graduate School of Business, Stanford University), MBA teaching (The Judge Business School, Cambridge University), consulting (Bain and Company, Menlo Park, California), and executive management (Shugart Corporation, Sunnyvale, California). He serves on the Boards of Directors and Advisory Boards of several tech companies. Dr. Evans has published widely in leading academic journals. His book "Super-Flexibility for Knowledge Enterprises", (second edition) was published by Springer.

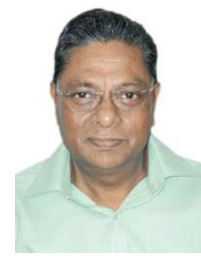

Sushil is Abdulaziz Alsagar Chair Professor (Professor of Strategic, Flexible Systems and Technology Management) and Chair, Strategic Management Group, Department of Management Studies, Indian Institute of Technology Delhi. He has served as Deputy Director (Operations) and Dean (Faculty) at IIT Delhi. He has served as Visiting Professor and delivered seminars in many leading universities, such as Kyoto University, Tokyo, University of Minnesota, Minneapolis, MN, Stevens Institute of Technology, NJ, University of Lethbridge, Alberta, Universite' Paris 1 Panthe'onSorbonne, Paris, among others. He is an active researcher and has supervised more than 60 doctoral dissertations. He has 20 books to his credit in the areas of Flexibility, Strategy, Systems Thinking, and Technology Management and over 300 papers in various refereed journals and conferences. He is the Founder Editor-in-chief of Global Journal of Flexible Systems Management and serving on the Editorial Boards of leading international journals. He is the Editor of Book Series on Flexible Systems Management published by Springer. 